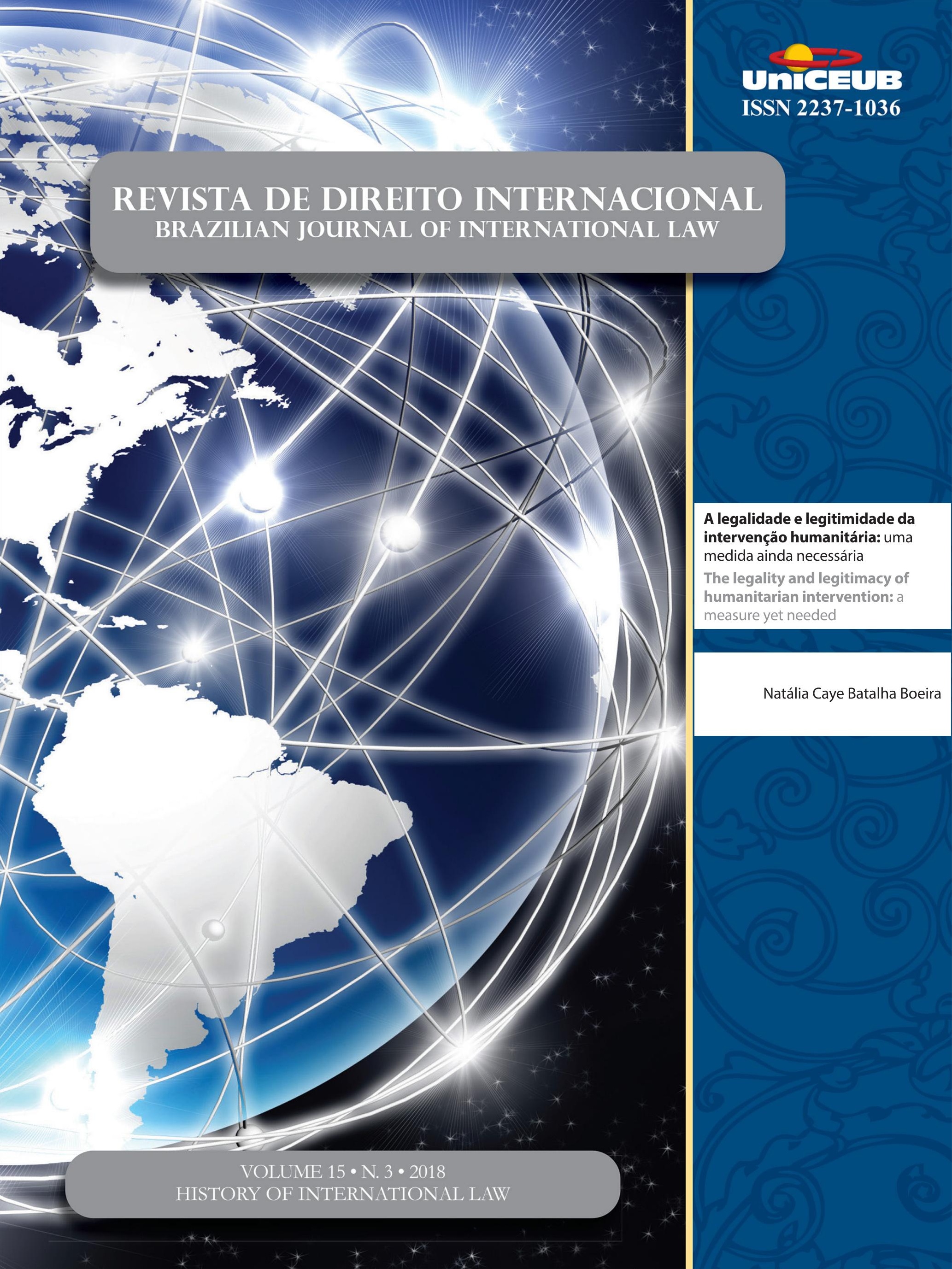




\section{Sumário}

I. Dossiê Especial: History of International Law ...................................1

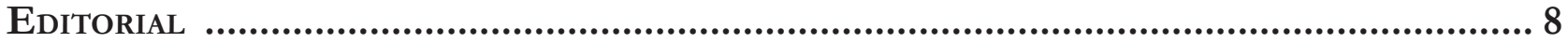

What does it mean to apply history in international law studies? ....................................................... 8

Arthur Roberto Capella Giannattasio

SuR LA NATURE DU Droit ISLAMIQUe............................................................................14

Hocine Benkheira

Islamic Shari’a Law, History and Modernity: Some Reflections .................................25 Suleiman A. Mourad

The (Un)practical Secularization Process: International Law and Religion as So-

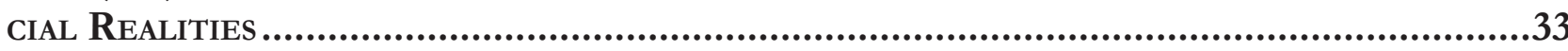

Douglas de Castro

BRAZILIAN LITERATURE ON INTERNATIONAL LAW DURING THE EMPIRE REGIME. OR THE DIFFUSION OF INTERNATIONAL LAW IN THE PERIPHERIES THROUGH APPROPRIATION AND ADAPTATION.

Airton Ribeiro da Silva Júnior

Natural, POSitivo, romano E Universal? INVESTigaÇão SObre O Direito das GENTES EM

Tomás de Aquino

Rafael Zelesco Barretto

II. Artigos sobre outros temas

VINCULAÇÃO DOS DIREITOS ECONÔMICOS, SOCIAIS E CULTURAIS: UMA DISCUSSÃO DO DESENVOLVImento humano com base no conceito de Amartya Sen sobre o mínimo existencial.....99

Natalia Mascarenhas Simões Bentes e Yasmim Salgado Santa Brígida

A NOVA LeI de MigraÇão E A PROTEÇão CONFERIDA AO APÁtrida: ALINHAMENTO BRASILEIRO AO PADRÃO INTERNACIONAL DE DIREITOS HUMANOS

Pedro Henrique de Faria Barbosa e Sylvio Loreto

E se o Supremo Tribunal Federal (STF) restabelecer a vigência da Convenção n. 158 
da Organização Internacional do Trabalho (OIT) na ordem Jurídica brasileira? SoBRE UMA POSSÍVEL REVIRAVOLTA, PELA VIA DO DIREITO INTERNACIONAL, DAS LEIS TRABALHISTAS BRASILEIRAS 138

Daniel Damasio Borges

JULGADOS DA CORTE INTERAMERICANA SOBRE CASOS BRASILEIROS E POLÍTICAS PÚBLICAS: REFLEXÕES ACERCA DE POSSÍVEIS INFLUIÇÕES 165

Rafael Osvaldo Machado Moura

CREATING BRIDGES BETWEEN INTERNATIONAL RELATIONS THEORY AND INTERNATIONAL HUMAN RIGHTS LAW: CONSTRUCTIVISM AND THE ROLE OF BRAZIL IN THE INTER-AMERICAN SYSTEM OF HUMAN RIGHTS 179

Ismael Francisco de Souza, Luciana Rocha Leme e Erick da Luz Scherf

Justiça de transição na Argentina e o Sistema Interamericano de Direitos Humanos: uMa ANÁlise do CASo Luis Muiña (“REgRa 2x1”) 199

Emilio Peluso Neder Meyer e Jessica Holl

A legalidade e legitimidade da INTERVEnÇão humanitÁria: UMA MEDIDA AINDA NECESSÁRIa.219 Natália Caye Batalha Boeira

O Acordo de Escazú E o ACESSo À INFORMaÇão AMbiental no Brasil. 252 Érica Bezerra Queiroz Ribeiro e Bruno Amaral Machado

Dos POVOS NATIVOS AO SURGIMENTO DOS MOVIMENTOS SOCIAIS: INFLUÊNCIAS DOS DISCURSOS JURÍDICOS, RELIGIOSOS E MÉDICOS PARA A CONSTRUÇÃO DO CONCEITO DE HOMOSSEXUALIDADE NO BRASIL .267 Bruno Rafael Silva Nogueira Barbosa e Robson Antão de Medeiros

Aspectos Jurídicos da PARTicipaÇão dA UNião Europeia NA OMC: COMPREENDENdo SUTILEZAS DE UM DELICADO ENLACE. 291

Camilla Capucio

Path to judicial activism? The use of "Relevant rules of international law" by the WTO Appellate Body

Mariana Clara de Andrade

LEVEZA E PESO NA MEDIAÇÃO COMERCIAL INTERNACIONAL: O CONTEÚDO JURÍDICO DO ACORDO CORPORATIVO MEDIADO E SUA INCORPORAÇÃo PELO DiREITO BRASILEIRO .324 Henrique Lenon Farias Guedes 
JURISDIÇÃO INTERNACIONAL E AS DIFICULDADES DE EXECUÇÃO DE SENTENÇAS INTERNACIONAIS NO BRASIL

Nevitton Vieira Souza

O DEVER DE COOPERAÇÃo NOS CONTRATOS DE VENDA INTERNACIONAL DE MERCADORIAS: PRESSUPOSTOS TEÓRICOS E REPERCUSSÕES PRÁTICAS DA CLÁUSULA GERAL DA BOA-FÉ OBJETIVA PARA A APLICAÇÃo DA CISG .358

Angelo Gamba Prata de Carvalho

A DiMENSÃo JURÍdiCA DO IMPERIALISMO NA (DES)ORDEM GLOBAL CAPITALISTA: UMA ANÁLISE COM BASE NA CRÍTICA MARXISTA AO DIREITO INTERNACIONAL E ÀS RELAÇÕES POLÍTICO-ECONÔMICAS DE DOMINAÇÃO E DEPENDÊNCIA.

Thomaz Delgado De David, Maria Beatriz Oliveira da Silva e Rosane Beatris Mariano da Rocha Barcellos Terra

A participaÇão de Brasil e Estados Unidos na formulação das regras multilaterais do

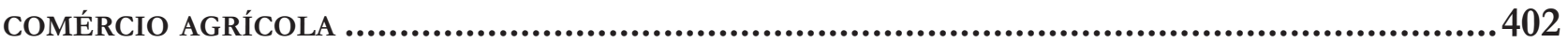

Vera Thorstensen, Vivian Daniele Rocha Gabriel e Alebe Linhares Mesquita

A galáxia lex e a construÇão de um Sistema jurídico transnacional ........................ 441

Eugênia Cristina Nilsen Ribeiro Barza e Jéssyka Maria Nunes Galvão

Has the Ability of Truth Commissions to Recommend Amnesty Been Effective in Enhancing Perpetrator Cooperation? 453 Jeremy Sarkin

A CONCEPTUAL PAPER ON THE POLICY-FRAMEWORK THAT MIRRORS THE DYNAMIC LINK BETWEEN Human Security, Social Protection and Safety Nets, and Food and Nutritional Security: The Case of the "Gulayan sa Paaralan Program", the Philippines.... 478 Renato Lagapa Base

INCENTIVISING SMALLHOLDER FARMER LIVELIHOODS AND CONSTRUCTING FOOD SECURITY THROUGH HOME-GROWN SCHOOL FEEDING: EVIDENCE FROM NORTHERN GHANA .491

Clement Mensah

Policy COHERENCE In THE IMPLEMENTATION OF THE 2030 AgENDA FOR SUSTAINABLE DEVELOpment: the Brazilian School Feeding Programme Case Study .506 Mariana Werlang Girardi 


\title{
A legalidade e legitimidade da intervenção humanitária: uma medida ainda necessária*
}

\author{
A legalidade e legitimidade da intervenção \\ humanitária: uma medida ainda necessária
}

Natália Caye Batalha Boeira**

\section{Resumo}

O presente artigo versa sobre a legalidade da intervenção humanitária frente à Carta das Nações Unidas, bem como debate acerca da existência de pressupostos objetivos para que a ação seja considerada legítima. Pode-se afirmar, frente aos princípios norteadores do Direito Internacional, que a intervenção humanitária é legal? Não se estaria ferindo a soberania dos estados com a intervenção, mesmo que por razões humanitárias? No que consiste sua legitimidade? Essas são as problemáticas que o artigo busca resolver, explicitando, com base na doutrina, documentos internacionais e resoluções do Conselho de Segurança, a possibilidade de que a intervenção militar humanitária seja considerada legal e legítima, superando a ideia de soberania absoluta dos Estados. Inicia-se com a conceituação de intervenção humanitária e como será tratada no artigo. A partir da evolução do Direito Internacional, que visa, cada vez mais, à salvaguarda dos direitos humanos, reconhecendo a responsabilidade secundária da comunidade internacional nessa tarefa, discorre-se sobre a legalidade da intervenção. O debate acerca do que legitima uma ação de força armada em defesa de direitos humanos é feito, trazendo-se os critérios existentes com base em dois documentos apresentados em debates internacionais, intitulados $A$ responsabilidade de proteger e $A$ responsabilidade ao proteger. É sustentada a legalidade da intervenção por estar contida dentro das possibilidades expostas no art. 42 da Carta ao Conselho de Segurança, como medida para restabelecimento da paz, sendo defendida, do mesmo modo, a existência de legitimidade quando são violadas normas de jus cogens, que consagram uma consciência moral da humanidade, elencando-se alguns necessários pressupostos para que a medida seja considerada legítima. Os dois termos — legitimidade e legalidade — não devem se confundir, precisando sua análise ser feita de forma autônoma.

Palavras-chave: Intervenção Humanitária. Legalidade. Conselho de Segurança.

* Recebido em: 21/11/2018 Aprovado em: 28/12/2018

** Bacharel em Direito pela Universidade do Vale do Rio dos Sinos (Unisinos). E-mail: naticaye@gmail.com

\section{Abstract}

The present article examines the legality of humanitarian intervention face the United Nations Letter and the existence of objective requirements so that an intervention can be considered legitimate. Can it be affirmed front the guiding principles of International Law that humanitarian intervention 
is legal? Doesn't the intervention go against state sovereignty? What does legitimacy consist of? These are questions the article seeks to solve, exposing, based on doctrine, international documents and Security's Council resolutions the possibility that humanitarian intervention be considered legal and legitimate, upending the idea of absolute sovereignty of States. The article begins with the conceptualization of humanitarian intervention and how it will be treated in the article. International Public Law has evolved with the objective of safeguarding human rights, placing the human person at the center of international relations as the final recipient of the norms of International Human Rights Law and International Security. Thus, the secondary responsibility of the international community for the protection of the most fundamental human rights is recognized, leading to the discussion of the legality of humanitarian intervention. What constitutes a legitimate intervention is discussed based on two important documents presented by the international community that generated the concept of The Responsibility to Protect and The Responsibility while Protecting. The legality of the intervention is sustained because it is contained within the possibilities set out in article 42 of the Charter allowing the Security Council to determine the intervention as a measure for the restoration of peace when faced with jus cogens norms violations, norms which consecrate humanity's moral conscience, listing some criterias that must be followed so that the measure can be considered legitimate. The two terms - legitimacy and legality - can not be confused, their analysis must be done autonomously.

Keywords: Humanitarian Intervention. Legality. Security Council.

\section{INTRODUÇÃo}

O presente artigo versa acerca da legalidade da intervenção militar humanitária frente aos princípios de Direito Internacional Público contidos na Carta das Nações Unidas, bem como aborda o dilema da legitimidade das intervenções, expondo os requisitos constantes atualmente em documentos elaborados pela comunidade internacional voltados especialmente para o assunto, ressaltando, no entanto, que não há pressupostos objetivos aceitos de forma unânime, tratando-se de um tema que ainda gera grandes debates internacionalmente.
A intervenção humanitária armada é uma medida extrema que vem sendo utilizada pelo Conselho de Segurança das Nações Unidas (CSNU), principalmente a partir do final da Guerra Fria, em situações de graves violações de direitos humanos que chocam a consciência da humanidade. O órgão, ao autorizar uma intervenção, afirma estar agindo sob o amparo do art. 42 da Carta das Nações Unidas, afirmando que as graves violações de direitos humanos são consideradas ameaças à paz e segurança internacionais.

A prática é considerada uma evolução da tradição da guerra justa, desenvolvida na idade média, em que se baseavam as razões para a guerra na moralidade e se buscava especificar quando seria justa/moral a utilização da força.

Trata-se de uma medida que busca resguardar as normas jus cogens, bem como garantir a efetiva eficácia da Organização das Nações Unidas (ONU), de modo que tenha uma última medida a qual recorrer quando um Estado-membro não cumpre suas obrigações, que se estendem desde seu povo até a comunidade internacional.

Apesar de ser um tema em que não se encontra consenso entre doutrinadores, é de extrema importância, uma vez que essa falta de consenso não impede sua prática, tanto unilateral quanto efetivamente determinada pelo CSNU.

A respeito desse dissenso problemática do presente artigo: a intervenção humanitária é legal frente aos princípios norteadores do Direito Internacional contidos na Carta das Nações Unidas? Se sim, quando será considerada legal? A legitimidade está contida na legalidade? Quando é possível afirmar que uma intervenção foi legítima?

As graves crises humanitárias, ocorridas no atual momento histórico, com o reiterado desrespeito aos princípios humanitários mais básicos, tornam evidente a importância da intervenção humanitária, uma vez que as operações de manutenção da paz (em que não há o uso da força para proteção de civis) acabam não sendo suficientemente eficazes quando atuam em um ambiente de extremo perigo.

As diversas intervenções ocorridas principalmente a partir dos anos 90 demonstraram a necessidade do debate sobre o assunto, a fim de traçar padrão de regularidade nos fundamentos das resoluções que determinam 
a intervenção humanitária, diante da ausência de requisitos objetivos na legislação que definem e delimitam quando e como deve-se recorrer à medida.

Assim, o objetivo do presente artigo consiste em analisar as respostas dadas aos questionamentos acima, tanto na doutrina como em documentos internacionais ${ }^{1}$ e informações disponíveis nos sítios oficiais dos órgãos envolvidos, sendo a pesquisa bibliográfica relacionada aos conceitos de guerra, soberania, uso da força, intervenções humanitárias, Direitos Humanos, Direito Humanitário e legitimidade, tanto de autores nacionais, como estrangeiros, em diversos ramos de estudo, uma vez que a problemática não deve se restringir ao ramo do Direito.

O artigo está estruturado em três partes, iniciando-se conceituação de intervenção humanitária abordado no presente estudo, considerando que, inclusive, sobre seu conceito, há divergências entre os pesquisadores.

Inicia-se o debate teórico com a análise da legalidade da intervenção, ou seja, se deve ser considerada ilegal frente aos princípios que regem o Direito Internacional, especialmente o Princípio da Não Intervenção, do não Uso da Força e da Soberania. Neste artigo, mostramos o desenvolvimento do Direito Internacional, estando cada vez mais voltado para questões humanitárias, o que gerou até mesmo um novo ramo nessa área: O Direito Internacional dos Direitos Humanos. Expomos também o Princípio da Soberania e o entendimento que deve se ter acerca deste, devendo gerar direitos e deveres aos Estados, o que não pode garantir a estes um passe livre para a tomada de qualquer atitude, devendo sempre prevalecer os direitos fundamentais dos cidadãos.

Posteriormente, buscamos responder às questões referentes à legitimidade da invenção: como pode ser a legitimidade entendida atualmente, expondo que o conceito não mais se esgota em uma análise positiva. Trazemos dois conceitos novos desenvolvidos com base em debates acerca das intervenções humanitárias: a responsabilidade de proteger e a responsabilidade ao proteger. A responsabilidade de proteção traz alguns requisitos norteadores para o Conselho de Segurança em relação

1 Analisaremos o documento elaborado pela Comissão Internacional sobre Intervenção e Soberania dos Estados (sigla em inglês: ICISS), intitulado a responsabilidade de proteger, bem como a nota conceitual com os elementos para o desenvolvimento e promoção do conceito responsabilidade ao proteger, apresentada à Assembleia Geral pela embaixadora do Brasil na ONU, Maria Luiza Ribeira Viotti. ao debate sobre a necessidade da determinação de uma intervenção, expondo alguns pressupostos objetivos necessários, e alguns que estão sujeitos a diferentes interpretações, permitindo a discricionariedade por parte do órgão em cada caso, trazendo debates de grande importância principalmente acerca da excepcionalidade que deve ser a medida. Já a responsabilidade ao proteger é um conceito novo apresentado pelo governo brasileiro que expõe a necessidade de controle também das intervenções durante sua execução para que não haja excessos e a fim de evitar que essa venha a causar mais malefícios que trazer benefícios.

A partir das considerações feitas no corpo do artigo, chega-se às considerações finais, concluindo que apesar de ainda haver muitas divergências, não se pode negar que a intervenção humanitária constitui prática legal do Conselho de Segurança quando utilizada para proteger a paz e segurança internacionais. As diversas resoluções, principalmente a partir dos anos 90, geram diversos precedentes para utilização da medida. Em contrapartida, deve-se desenvolver critérios mais objetivos para controlar o poder discricionário do órgão quanto ao uso da força, uma vez que os critérios apresentados pela Comissão Internacional sobre Intervenção e Soberania dos Estados (sigla em inglês: ICISS), apesar de serem aparentemente objetivos, ainda deixam totalmente nas mãos do Conselho a análise das situações que exigem a intervenção humanitária, e as que não, o que ocasiona uma falta de padrão nas decisões. Além disso, mostra-se necessário uma reforma ou constituição de um novo órgão no qual os representantes possam ser imparciais, não agindo sob pretextos políticos de seus governos, a fim de, efetivamente, garantir-se que a intervenção seja utilizada como medida de proteção das normas jus cogens, e não qualquer outra justificação inidônea.

\section{O CONCEITO DE INTERVENÇÃO HUMANITÁRIA}

Apesar de ter suas origens na tradição da Guerra Justa, a Intervenção Humanitária não pode ser confundida com a guerra, porquanto a guerra é um status jurídi$c o$, caracterizado pela situação de caos supremo, sendo admitida atualmente, por meio de uma perspectiva legal, apenas em casos de legítima defesa (art.51 Carta); enquanto a intervenção, por sua vez, visa cessar o caos. ${ }^{2}$

2 MELlO, Celso Duvivier de Albuquerque. Direitos Humanos e 
A guerra tem a finalidade individualista de forçar um dos adversários a satisfazer as vontades do outro ${ }^{3}$, sendo esta a grande diferença das intervenções humanitárias, que devem visar tão somente à cessão das atrocidades. O motivo causador (principal) da intervenção deve ser a grave violação de direitos humanos; ou seja, a intervenção deve ocorrer em prol da humanidade. Por tal razão, não concordamos com Gisele Ricobom quando conceitua intervenção humanitária como guerra em nome dos direitos bumanos ${ }^{4}$. A intervenção pode ocorrer em decorrência da guerra, mas esta não pode ser confundida com aquela.

Não há definição normativa do conceito de intervenção humanitária ${ }^{5}$, buscamos, portanto, sua conceituação na doutrina.

Intervenção Humanitária, conforme Fernando Tesón ${ }^{6}$, é:

[...] a ajuda proporcional transfonteiriça, incluindo ajuda forçada, fornecida por governos a indivíduos em outro estado que estão sendo negados direitos humanos básicos e que, eles mesmos, estariam racionalmente dispostos a se revoltar contra o governo opressivo. (Tradução nossa).

Cody, por sua vez, define separadamente o conceito de intervenção e de humanitária. Intervenção é "[...] ]o ato intencional de um estado ou grupo de estado ou agência internacional visando exercitar autoridade superior no que geralmente são políticas internas[...]"7 (tradução nossa), sem que haja a anuência do intervido. Já a expressão bumanitária está ligada à causa principal da inter-

Conflitos Armados. Rio de Janeiro: Renovar, 1997. p. 107-113.

3 MAZZUOLI, Valerio de Oliveira. Curso de Direito Internacional Público. 8. ed. rev. atual. e ampl. São Paulo: Revista dos Tribunais, 2014. p. 1175.

4 RICOBOM, Gisele. Intervenção Humanitária: a guerra em nome dos direitos humanos. Belo Horizonte: Fórum, 2010.

5 RODRIGUES, Simone Martins. Segurança Internacional e Direitos Humanos: a prática da intervenção humanitária no pós-Guerra Fria. Rio de Janeiro: Renovar, 2000. p. 91.

6 "[... the proportionate transboundary help, including forcible help, provided by governments to individuals in another state who are being denied basic human rights and who themselves would be rationally willing to revolt against their opressive government." TESÓN, Fernando R. Humanitarian Intervention: an inquiry into law and morality. 2. ed. New York: Transnational, 1997. p. 5.

7 " [...] an intentional act of one state or group of states or an international agengy aimed at exercising overriding authority on what are normally the 'internal' policies or practices of another state or group of states". COADY, C. A. J. The Ethics of Armed Humanitarian Intervention. 2002. p. 10. Disponível em: http://citeseerx.ist.psu. $\mathrm{edu} / \mathrm{viewdoc} /$ download?doi $=10.1 .1 .197 .8523 \& \mathrm{rep}=$ rep1\&type $=\mathrm{p}$ df. Acesso em: 11 jan. 2018. venção, que deve ser altruísta. ${ }^{8}$

Holzgrefe trabalha com o termo definido como:

[...]a ameaça ou o uso da forca para além das fronteiras de outro Estado, por um Estado (ou grupo de Estados), com o objetivo de prevenir ou cessar violações graves e generalizadas de direitos humanos fundamentais dos indivíduos que não sejam cidadãos da força interventora, sem a permissão do Estado cujo território a força é aplicada. (Tradução nossa). ${ }^{9}$

Simone Martins Rodrigues expõe os três elementos trazidos por Bhikhu Parekhu necessários para caracterizar uma intervenção: “[...]o objeto da ação deve ser um estado soberano, que se opõe à ingerência externa, e a intervenção tem de representar um esforço de influenciar sua conduta doméstica[...]"10, além do necessário aspecto humanitário como motivador primário da decisão de intervir. ${ }^{11}$

Há, no entanto, autores que afirmam que também é caracterizada como intervenção toda e qualquer ingerência nos assuntos internos dos estados, podendo ser ela diplomática, armada e econômica. ${ }^{12}$

Apesar de haver diversos tipos de intervenção humanitária, sem que haja consenso a respeito de sua delimitação na doutrina, no presente artigo nos limitaremos à análise da intervenção militar humanitária, ou seja, às intervenções armadas e coercitivas que visam à cessão da violação dos direitos mais fundamentais do ser humano.

8 COADY, C. A. J. The Ethics of Armed Humanitarian Intervention. 2002. p. 10. Disponível em: http://citeseerx.ist.psu.edu/viewdoc/ download?doi=10.1.1.197.8523\&rep=rep1\&type=pdf. Acesso em: 11 jan. 2018. p. 11.

9 " $[\ldots]$ the threat or use of force across state borders by a state (or group of states) aimed at preventing or ending widespread and grave violations of the fundamental human rights of individual other than its own citizens, without the permission of the sate within whose territory force is applied." HOLZGREFE, J. H. Humanitarian Intervention: ethical, legal and political dilemmas. Cambridge: Cambridge University Press, 2002. Disponível em: https://books.google. com.br/books?id=luPNuThpx6QC\&printsec $=$ frontcover\&hl=pt$\mathrm{BR} \&$ source $=$ gbs_ge_summary_r\&cad $=0 \#_{\mathrm{v}}=$ onepage\&q\&f$=$ false. Acesso em: 12 fev. 2018.

10 RODRIGUES, Simone Martins. Segurança Internacional e Direitos Humanos: a prática da intervenção humanitária no pós-Guerra Fria. Rio de Janeiro: Renovar, 2000. p. 96-7.

11 RODRIGUES, Simone Martins. Segurança Internacional e Direitos Humanos: a prática da intervenção humanitária no pós-Guerra Fria. Rio de Janeiro: Renovar, 2000. p. 96-7.

12 MELLO, Celso D. De Albuquerque. Curso de Direito Internacional Público. Rio de Janeiro: Renovar, 2001. p. 469. v. 1 


\section{A legalidade na intervenção}

A intervenção militar humanitária possibilitada pelo texto do art. 42 da Carta das Nações Unidas é uma das possíveis medidas a ser tomada pelo Conselho de Segurança como forma de proteção da paz. Tornou-se prática recorrente no período pós-Guerra Fria, momento em que se apaziguaram as relações entre os Estados que compõem o órgão. No entanto, ainda hoje há grande debate acerca da licitude de tal medida, tendo em vista que fere princípios norteadores do Direito Internacional: o princípio da soberania estatal (art. 2.1 da Carta), da não intervenção (art. 2.7) e da proibição do uso da força (art. 2.4)..$^{13}$

Além disso, não existem critérios objetivos estabelecidos na legislação que permitem uma análise imparcial e igualitária de cada situação, fazendo com que o CSNU fundamente suas decisões em preceitos extralegais, muitas vezes não esclarecidos em suas resoluções, que com habitualidade compreendem a justificativa da intervenção por haver grave violação dos direitos humanos, que constitui ameaça à paz e segurança internacional, restringindo-se a afirmação de que o Conselho age sob o amparo do Capítulo VII da Carta. ${ }^{14}$

Diante dessas problemáticas, surge a divergência acerca da legalidade ou não das intervenções humanitárias, a seguir analisada.

\subsection{A Humanização do Direito Internacional}

A primeira forma de intervenção humanitária na prática internacional foi aquela que visava a proteção dos direitos de súditos estrangeiros contra um governante opressor ${ }^{15}$; não obstante, foi somente a partir do final da I Guerra Mundial, diante das atrocidades en-

13 RODRIGUES, Simone Martins. Segurança Internacional e Direitos Humanos: a prática da intervenção humanitária no pós-Guerra Fria. Rio de Janeiro: Renovar, 2000. p. 107-9.

14 Exemplos: ASSEMBLEIA GERAL DAS NAÇÕES UNIDAS. Security Council. Resolution 794 (1992). S/RES/794 (1992). Disponível em: http://www.un.org/en/ga/search/view_doc. asp?symbol=S/RES/794(1992). Acesso em: 5 mar. 2018; ASSEMBLEIA GERAL DAS NAÇÕES UNIDAS. Security Council. Resolution 824 (1993). S/RES/824 (1993). Disponível em: http://www. un.org/en/ga/search/view_doc.asp?symbol=S/RES/824(1993). Acesso em: 5 mar. 2018.

15 RODRIGUES, Simone Martins. Seguranç Internacional e Direitos Humanos: a prática da intervenção humanitária no pós-Guerra Fria. Rio de Janeiro: Renovar, 2000. p. 92. frentadas e com uma maior conscientização das consequências da guerra que, com a criação da Liga das Nações (1919-1939), buscou-se, efetivamente, restringir o jus ad bellum. ${ }^{16}$

O Pacto Kellogg-Briand (ou Pacto de Paris), assinado em 1928, condenava o recurso à guerra como método de solução de controvérsias internacionais, rompendo a doutrina da guerra justa. ${ }^{17}$ Apesar de seu fracasso pelo advento da II Guerra Mundial, é considerado um marco histórico por ser o primeiro pacto que formalizou uma proposta de total renúncia à guerra. ${ }^{18}$

Portanto, não obstante a criminalização da guerra, estas continuam a existir, devendo o direito buscar formas de mitigar o sofrimento das vítimas inevitáveis quando se está diante de um conflito armado, ainda que para isso seja necessário o uso da força (em prol dos direitos humanos). Assim, o uso da força passa a ser entendido como um mal a ser evitado, porém, às vezes, necessário. ${ }^{19} \mathrm{Ou}$ seja, ainda que em casos de guerra, deve-se respeitar um direito mínimo das partes: o chamado Direito Internacional Humanitário. ${ }^{20}$ Frisa-se que é o

16 MEZZANOTTI, Gabriela. Direito, Guerra e Terror: Os novos desafios do Direito Internacional pós 11 de setembro. São Paulo: Quartier Latin, 2007. p. 28.

17 MIALHE, Jorge Luis. Considerações sobre a história do direito das relações internacionais: jus in bello, guerra justa e a ONU. In: MIALHE, Jorge Luis (org.). Direito das Relações Internacionais: Ensaios Históricos e Jurídicos. São Paulo: Milennium, 2007. p. 157-8.

18 PACTO Briand-Kellog. Disponível em: http://cpdoc.fgv.br/ sites/default/files/verbetes/primeira-republica/PACTO\%20BRIAND-KELLOG.pdf. Acesso em: 4 mar. 2018.

19 Preâmbulo da Carta: "[...]unir as nossas forças para manter a paz e a segurança internacionais, e a garantir, pela aceitação de princípios e a instituição dos métodos, que a força armada não será usada a não ser no interesse comum[...]". BRASIL. Decreto $n^{\circ}$ 19.841, de 22 de outubro de 1945. Promulga a Carta das Nações Unidas, da qual faz parte integrante o anexo Estatuto da Corte Internacional de Justiça, assinada em São Francisco, a 26 de junho de 1945, por ocasião da Conferência de Organização Internacional das Nações Unidas. Disponível em: http://www.planalto.gov.br/ccivil_03/decreto/1930-1949/d19841.htm. Acesso em: 12 abr. 2018.

20 O Direito Internacional Humanitário (DIH) é área do Direito Internacional que busca estabelecer normas básicas para evitar a crueldade cega e implacável em conflitos armados, sendo o anteriormente denominado jus in bello. Swinarski define o DIH como: [...] o conjunto de normas internacionais, de origem convencional ou consuetudinária, especificamente destinado a ser aplicado nos conflitos armados, internacionais ou não internacionais, e que limita, por razões humanitárias, o direito das Partes em conflito de escolher livremente os métodos e os meios utilizados na guerra, ou que protege as pessoas e os bens afetados, ou que possam ser afetados pelo conflto. Em: SWINARSKI. Christophe. Introdução ao Direito Internacional Humanitário. Brasília: Comitê Internacional da Cruz Vermelha e Instituto Interamericano de Direitos Humanos, 1996. p. 11. 
Tribunal Internacional Penal, criado a partir do Estatuto de Roma em 1998, que tem, dentre os crimes de sua competência, os atos de agressão e crimes de guerra. ${ }^{21}$

Aron analisa que não basta a mera existência de norma legal, se em desacordo às realidades da sociedade internacional (tratava-se de normas de soft law), afirmando que "quem imaginava garantir a paz declarando a guerra contrária à lei pensava como um médico que pensasse poder curar uma doença declarando-a contrária às aspirações da humanidade". ${ }^{22}$ Dessa forma o autor faz uma crítica à norma criada com aspectos idealistas, sem que seja condizente com a realidade fática do período, de modo a se tornar ineficaz.

Assim, após o final da II Guerra Mundial, com a criação da Organização das Nações Unidas (ONU), a fim de preservar a paz, fica estabelecido pela Carta das Nações Unidas que a guerra é um meio ilícito de solução de controvérsias internacionais ${ }^{23}$, sendo estabelecidas sanções em caso de descumprimento, visando, especialmente, à proteção da pessoa humana e os direitos a ela inerentes. ${ }^{24}$ Dessarte, a Carta estabelece meios de efetivar as normas, vinculando-se "cada vez mais os Estados aos seus deveres internacionais dando justo realce e alcance objetivo à função coordenadora do direito". ${ }^{25}$

Essa proteção da pessoa humana no âmbito internacional está ligada ao surgimento, após a segunda grande guerra, de um novo ramo do Direito Internacional: o Direito Internacional dos Direitos Humanos. Ele se forma com a entrada em vigor da Carta, que reconhece que os seres humanos têm direitos sob o Direito Internacional e que a violação de tais direitos enseja na responsabilidade da comunidade internacional. Tanto o Direito Internacional Humanitário, como o Direito Internacional dos Direitos Humanos têm como finalidade a proteção da pessoa humana, sendo, aquele, no entanto, específico para os casos em que há conflito ar-

21 BORGES, Leonardo Estrela. O Direito Internacional Humanitário. Belo Horizonte: Del Rey, 2006. p. 2.

22 ARON, Raymond. Paz e Guerra entre as Naçoes. Brasília, DF: Editora Universidade de Brasília; São Paulo: Imprensa Oficial do Estado de São Paulo, 2002. p. 708.

23 MAZZUOLI, Valerio de Oliveira. Curso de Direito Internacional Público. 8. ed. rev. atual. e ampl. São Paulo: Revista dos Tribunais, 2014. p. 1174.

24 CASSESE, Antonio. Existe um conflito insuperável entre soberania dos Estados e justiça penal internacional? In: CASSESE, Antonio; DELMAS-MARTY, Mireille (org.). Crimes Internacionais e Jurisdições Internacionais. São Paulo: Manole, 2004. p. 13.

25 ITUASSÚ, Oyama Cesar. Curso de Direito Internacional Público. Rio de Janeiro: Forense, 1986. p. 696. mado. ${ }^{26}$

Com a criação da ONU, há grande crescimento no surgimento de documentos internacionais visando à salvaguarda dos direitos fundamentais do homem, sendo o mais importante deles A Declaração Universal dos Direitos Humanos de 1948, que deve ser utilizada em combinação com os princípios tipificados na $\mathrm{Carta}^{27}$

É a partir desse crescimento e da compreensão de que a proteção dos direitos fundamentais não deve se esgotar na atuação interna de cada Estado que, em 1960, o Conselho de Segurança (CSNU) aprova a resolução $134^{28}$, vinculando, pela primeira vez, uma questão de direitos humanos à ameaça à paz e segurança internacionais. ${ }^{29}$

Não obstante a falta de previsão expressa na Carta das Nações Unidas que garanta a possibilidade de o Conselho de Segurança determinar a intervenção humanitária, a legalidade e competência do CSNU, conforme as decisões do próprio órgão, advém da previsão expressa no art. 39, que afirma caber ao Conselho determinar a existência de qualquer ameaça à paz, ruptura da paz ou ato de agressão, e fará recomendações ou decidirá que medidas deverão ser tomadas de acordo com os Artigos 41 e 42, a fim de manter ou restabelecer a paz e a segurança internacionais. ${ }^{30}$

26 TRINDADE, Antônio Augusto Cançado. A Proteção Internacional dos Direitos Humanos: Fundamentos jurídicos e instrumentos básicos. São Paulo: Saraiva, 1991. p. 3-18.

27 TRINDADE, Antônio Augusto Cançado. A Proteção Internacional dos Direitos Humanos: Fundamentos jurídicos e instrumentos básicos. São Paulo: Saraiva, 1991. p. 2.

28 O parágrafo primeiro afirmava que levando em consideração a grave preocupação entre os governos e pessoas do mundo pelos acontecimentos da União da África do Sul, o Conselho: "1. Recongnizes that the situation in the Union of South Africa is one that has led to international friction and if continued might endager international peace and security." RESOLUTIONS Adopted and Decisions Taken by the Security Council in 1960. Disponível em: http://www. un.org/en/ga/search/view_doc.asp?symbol=S/RES/134(1960). Acesso em: 04 fev. 2018.

29 GHISLENI, Alexandre Peña. Direitos Humanos e Segurança Internacional: o tratamento dos temas de Direitos Humanos no Conselho de Segurança das Nações Unidas. Brasília: Fundação Alexandre de Gusmão, 2011. p. 32. Disponível em: http://funag.gov.br/loja/ download/857-Direitos_Humanos_e_Seguranca_Internacional. pdf. Acesso em: 03 jan. 2018.

30 Art. 39. BRASIL. Decreto $n^{\circ}$ 19.841, de 22 de outubro de 1945. Promulga a Carta das Nações Unidas, da qual faz parte integrante o anexo Estatuto da Corte Internacional de Justiça, assinada em São Francisco, a 26 de junho de 1945, por ocasião da Conferência de Organização Internacional das Nações Unidas. Disponível em: http:// www.planalto.gov.br/ccivil_03/decreto/1930-1949/d19841.htm. Acesso em: 19 fev. 2018. 
Isso porque a violação da paz e ato de agressão estão ligados aos direitos humanos, considerando o impacto que o conflito pudesse causar (conforme restou decidido na resolução 134 de $\left.1960^{31}\right) .{ }^{32}$

Ainda, além de buscar manter a paz e segurança internacionais, outro objetivo da organização, conforme contido no preâmbulo da Carta é " [...]reafirmar a fé nos direitos fundamentais do homem, na dignidade e no valor do ser humano[...]"33, também reafirmado pelo art. 1.3, de modo que a legalidade também se encontra firmada nos dois principais pilares das Nações Unidas: paz internacional e direitos humanos. ${ }^{34}$

Dessa forma, o conceito aberto de ameaça à paz e atos de agressão pode remeter à proteção dos direitos humanos, de modo que se torna legal o tratamento de temas de direitos humanos pelo Conselho, desde que sua gravidade constitua ameaça à paz e segurança internacionais. Tal ideia está entrelaçada com a humanização do Direito Internacional, ocorrida, principalmente, a partir da criação da ONU e com o surgimento do Direito Internacional dos Direitos Humanos. ${ }^{35}$

A mobilização da comunidade internacional para assegurar uma proteção eficaz do ser humano é referida por Antônio Augusto Trindade como consequência do "[...] despertar de uma consciência jurídica universal[...]"36 (tradução nossa) para a prevalência da dignidade da pessoa humana em qualquer situação. $\mathrm{O}$ autor defende a neces-

31 GHISLENI, Alexandre Peña. Direitos Humanos e Segurança Internacional: o tratamento dos temas de Direitos Humanos no Conselho de Segurança das Nações Unidas. Brasília: Fundação Alexandre de Gusmão, 2011. p. 32. Disponível em: http://funag.gov.br/loja/ download/857-Direitos_Humanos_e_Seguranca_Internacional. pdf. Acesso em: 03 jan. 2018.

32 GHISLENI, Alexandre Peña. Direitos Humanos e Segurança Internacional: o tratamento dos temas de Direitos Humanos no Conselho de Segurança das Nações Unidas. Brasília: Fundação Alexandre de Gusmão, 2011. p. 50-1. Disponível em: http://funag.gov.br/loja/ download/857-Direitos_Humanos_e_Seguranca_Internacional. pdf. Acesso em: 03 jan. 2018.

33 Preâmbulo da Carta.

34 ANNAN, Kofi A. Intervenções: uma vida de guerra e paz. São Paulo: Companhia das Letras, 2013. p. 151.

35 TRINDADE, Antônio Augusto Cançado. A Proteção Internacional dos Direitos Humanos: Fundamentos jurídicos e instrumentos básicos. São Paulo: Saraiva, 1991. p. 3-18.

36 "[...] despertar de la conciencia jurídica universal[...]". TRINDADE, Antônio Augusto Cançado; SANTIAGO, Jaime Ruiz de. La Nueva Dimensión de las Necesidades de Protección del Ser Humano en el Inicio del Siglo XXI. 2. ed. San José, C.R: Impresora Gossestra Internacional, 2002. p. 63. Disponível em: http://www.acnur.org/t3/ fileadmin/Documentos/Publicaciones/2012/8946.pdf?view $=1$. Acesso em: 13 abr. 2018. sidade de conciliação entre a ordem legal e a ordem moral, de modo que as questões de direitos humanos não devem ser abordadas tão somente com base em uma perspectiva positivista. O Direito Internacional deve estar em constante desenvolvimento, sempre sendo direcionado ao ser humano, destinatário final das suas normas de proteção. ${ }^{37}$

A proteção do indivíduo no âmbito internacional está diretamente entrelaçada com o sistema (ou princípio, como referido por alguns autores $\left.{ }^{38}\right)$ da segurança coletiva, uma vez que a adesão dos Estados a instrumentos internacionais de proteção de direitos humanos “[...] só possuem conteúdo real quando o mecanismo de responsabilização por violações é eficaz[...]"39, a fim de se evitar o caráter meramente programático de tais normas. $^{40}$

\subsection{O Conceito de Segurança Coletiva}

Criado com a Liga das Nações, o princípio da segurança coletiva remetia a uma ideia de proteção conjunta de todos estados-membros em caso de ameaça da segurança de qualquer Estado. ${ }^{41}$ Tal princípio/sistema foi restabelecido após a Segunda Guerra Mundial com

37 "[...] despertar de la conciencia jurídica universal[...]". TRINDADE, Antônio Augusto Cançado; SANTIAGO, Jaime Ruiz de. La Nueva Dimensión de las Necesidades de Protección del Ser Humano en el Inicio del Siglo XXI. 2. ed. San José, C.R: Impresora Gossestra Internacional, 2002. p. 63-9. Disponível em: http://www.acnur.org/t3/ fileadmin/Documentos/Publicaciones/2012/8946.pdf?view=1. Acesso em: 13 abr. 2018.

38 Dentre os quais: PINTO, Maria do Céu. As Nações Unidas e a Manutenção da Pą: e as actividades de peacekeeping doutras organizações internacionais. Coimbra: Almedina, 2007; REZENDE, Lucas Pereira; AZEVEDO, Cesar Augusto Lambert de. ABRI. Associação Brasileira de Relações Internacionais. Carta Internacional. Sobre o Sistema de Segurança Coletiva e a Legitimidade das Operações de Paz. da ONU, v. 6, n. 1, 2011. Disponível em: https://cartainternacional. abri.org.br/Carta/article/view/22. Acesso em: 28 mar. 2018.

39 RAMOS, André de Carvalho. Processo Internacional de Direitos Humanos: análise dos sistemas de apuração de violações de direitos humanos e implementação das decisões no Brasil. Rio de Janeiro: Renovar, 2002. p. 9.

40 RAMOS, André de Carvalho. Processo Internacional de Direitos Humanos: análise dos sistemas de apuração de violações de direitos humanos e implementação das decisões no Brasil. Rio de Janeiro: Renovar, 2002. p. 9.

41 REZENDE, Lucas Pereira; AZEVEDO, Cesar Augusto Lambert de. ABRI. Associação Brasileira de Relações Internacionais. Carta Internacional. Sobre o Sistema de Segurança Coletiva e a Legitimidade das Operações de Paz da ONU, v. 6, n. 1, p. 24, 2011. Disponível em: https://cartainternacional.abri.org.br/Carta/article/view/22. Acesso em: 28 mar. 2018. p. 24. 
a criação da $\mathrm{ONU}$, visando prevenir o uso unilateral da força pelos estados (excetuando-se a legítima defesa), bem como a existência de uma autoridade internacional (a própria Organização), que atuaria como força policial internacional através do Conselho de Segurança. ${ }^{42}$

Sutterlin afirma que, dentre as principais razões para o fracasso da Liga, se encontra a inefetividade das sanções contra estados não obedientes, devendo a ONU, portanto, ter um sistema de imposição mais efetivo. ${ }^{43}$ Assim, não obstante exista a previsão na Carta da possibilidade do exercício da legítima defesa individual ou coletiva, essas são restringidas ${ }^{44}$, tendo o Conselho de Segurança o monopólio de autorização acerca de medidas coercitivas, ${ }^{45}$ de modo a manter a paz e resguardar a segurança internacional, agindo no desempenho de suas funções em nome dos membros da organização (que concordam em aceitar e executar suas decisões, conforme art. 25 da Carta). ${ }^{46}$

\section{Henry Kissinger expõe que:}

Segurança coletiva não define uma ameaça em

42 RAMOS, André de Carvalho. Processo Internacional de Direitos Humanos: análise dos sistemas de apuração de violações de direitos humanos e implementação das decisões no Brasil. Rio de Janeiro: Renovar, 2002. p. 168.

43 SUTTERLIN, James S. The United Nations and the Maintenance of International Security. A Challenge To Be Met. Praeger. 1995. p. 3. Disponível em: https://books.google.com.br/ books?hl $=$ pt-BR\&lr $=\& \mathrm{id}=\mathrm{dY}$ istZdU8AQC\&oi $=$ fnd $\& \mathrm{pg}=\mathrm{PA} 1 \& \mathrm{~d}$ $\mathrm{q}=$ The + United + Nations + and + the + Maintenance + of + Internation $\mathrm{al}+$ Security\&ots $=\mathrm{cdu} 8$ pexCPS\&sig $=\mathrm{xYGa9I}-08$ Dqc $4 \mathrm{c}$ Ahbuqrg0678w \#v=onepage\&q\&f=false $>$. Acesso em: 28 mar. 2018.

44 "Artigo 51. Nada na presente Carta prejudicará o direito inerente de legítima defesa individual ou coletiva no caso de ocorrer um ataque armado contra um Membro das Nações Unidas, até que o Conselho de Segurança tenha tomado as medidas necessárias para a manutenção da paz e da segurança internacionais. As medidas tomadas pelos Membros no exercício desse direito de legítima defesa serão comunicadas imediatamente ao Conselho de Segurança e não deverão, de modo algum, atingir a autoridade e a responsabilidade que a presente Carta atribui ao Conselho para levar a efeito, em qualquer tempo, a ação que julgar necessária à manutenção ou ao restabelecimento da paz e da segurança internacionais." (Grifo osso). BRASIL. Decreto $n^{\circ}$ 19.841, de 22 de outubro de 1945. Promulga a Carta das Nações Unidas, da qual faz parte integrante o anexo Estatuto da Corte Internacional de Justiça, assinada em São Francisco, a 26 de junho de 1945, por ocasião da Conferência de Organização Internacional das Nações Unidas. Disponível em: < http://www.planalto.gov.br/ccivil_03/decreto/1930-1949/d19841.htm. Acesso em: 27 fev. 2018.

45 PATRIOTA, Antonio de Aguiar. O Conselho de Segurança após a Guerra do Golfo: a articulação de um novo paradigma de segurança coletiva. Brasília: Instituto Rio Branco, 1998. p. 24.

46 "Artigo 25. Os Membros das Nações Unidas concordam em aceitar e executar as decisões do Conselho de Segurança, de acordo com a presente Carta." BRASIL. Decreto $n^{\circ} 19.841$, de 22 de outubro de 1945. particular, não garante uma nação individual, e não discrimina ninguém. É teoricamente designada para resistir qualquer ameaça à paz, por qualquer um que ameaçá-la e contra quem possa estar direcionada. ${ }^{47}$ (Tradução nossa).

O capítulo VII da Carta, que prevê a possibilidade de o Conselho de Segurança tomar medidas militares nos casos em que há ameaça à paz, ruptura da paz ou ato de agressão, é associado por Antônio de Aguiar Patriota como um sinônimo de segurança coletiva. ${ }^{48}$ No entanto, concordamos com a afirmação de Maria do Céu Pinto, que leciona ser a principal ideia da segurança coletiva a proteção de determinados valores, derivando as medidas previstas no capítulo VII da necessidade de sustentar o referido princípio. ${ }^{49}$

Eduardo Uziel elenca as principais características da segurança coletiva, quais sejam:

1) a paz como objetivo último, sendo a guerra, em princípio, banida, e a conquista territorial ilegal; 2) a agência organizadora das ações de segurança coletiva é de composição quase universal e opera por um princípio, ainda que matizado, de igualdade soberana; 3) as decisões sobre ações a serem empreendidas em conflitos armados são tomadas por órgãos coletivos e, ao menos do ponto de vista formal, representativos, constituídos anteriormente aos casos com os quais lidam. ${ }^{50}$

Assim, a possibilidade da intervenção humanitária advém de uma ideia de segurança coletiva, sendo parte integral desse mecanismo, de forma a resguardar a paz mundial, mesmo que para isso tenha de invadir a chamada esfera de direitos dos Estados. ${ }^{51}$

Importante ressaltar que a segurança coletiva, como prevista na Carta, é efetuada pelo Conselho de Seguran-

47 "Collective security defines no particular threat, guarantees no individual nation, and discriminates against none. It is theoretically designed to resist any threat to the peace, by whomever might pose it and against whomever it might be directed." KISSINGER, Henry. Diplomacy. New York: Simon \& Schuster, 1994. p. 247. Diponível em: https://archive.org/stream/kissingerdiplomacy4/ Henry\%20Kissinger\%20-\%20Diplomacy\#page/n241/mode/2up/ search/247. Acesso em: 22 fev. 2018.

48 PATRIOTA, Antonio de Aguiar. O Conselho de Segurança após a Guerra do Golfo: a articulação de um novo paradigma de segurança coletiva. Brasília: Instituto Rio Branco, 1998. p. 24.

49 PINTO, Maria do Céu. As Nações Unidas e a Manutenção da Pą: e as actividades de peacekeeping doutras organizações internacionais. Coimbra: Almedina, 2007. p. 33.

50 UZIEL, Eduardo. O Conselho de Segurança, as Missões de Paz e o Brasil no Mecanismo de Segurança das Naçôes Unidas. Brasília: FUNAG, 2015. p. 36.

51 ITUASSÚ, Oyama Cesar. Curso de Direito Internacional Público. Rio de Janeiro: Forense, 1986. p. 693. 
ça, estando os Estados, unilateralmente, proibidos de utilizar a força (por força do art. 2.4), a não ser em casos de legítima defesa (art. 51).

$\mathrm{O}$ art. 51 da Carta traz a possibilidade de legítima defesa coletiva, no entanto, o próprio artigo faz ressalva que esse direito não deverá atingir a autoridade e responsabilidade do Conselho, assim dispondo:

\begin{abstract}
Artigo 51. Nada na presente Carta prejudicará o direito inerente de legítima defesa individual ou coletiva no caso de ocorrer um ataque armado contra um Membro das Nações Unidas, até que o Conselho de Segurança tenha tomado as medidas necessárias para a manutenção da paz e da segurança internacionais. As medidas tomadas pelos Membros no exercicio desse direito de legítima defesa serão comunicadas imediatamente ao Conselho de Segurança e não deverão, de modo algum, atingir a autoridade e a responsabilidade que a presente Carta atribui ao Conselho para levar a efeito, em qualquer tempo, a ação que julgar necessária à manutenção ou ao restabelecimento da paz e da segurança internacionais. ${ }^{52}$ (Grifo nosso).
\end{abstract}

Dessa forma não restam dúvidas que ao falar em legalidade da intervenção essa só pode ser autorizada pelo Conselho de Segurança, que tem monopólio para autorizar/determinar as medidas coercitivas, exercendo a segurança coletiva, representando os estados-membros ${ }^{53}$.

Ressalvamos que com a resolução Unidos pela $\mathrm{Paz}^{54}$ foi conferida à Assembleia Geral papel complementar ao do CSNU, no sentido de, quando este estiver paralisado pelo veto, a Assembleia pode fazer recomendações a assuntos referentes à proteção da paz e segurança internacionais (ressaltamos que as decisões da Assembleia não têm força vinculante). ${ }^{55}$

Não obstante, ainda que em nome da proteção dos direitos humanos, a invasão nos assuntos internos dos estados se mostra tema de grande divergência na doutrina, sendo defendido por alguns a supremacia do princípio da soberania. ${ }^{56}$ Apesar disso, mostraremos a seguir

52 Art. 51. BRASIL. Decreto $n^{0}$ 19.841, de 22 de outubro de 1945. Promulga a Carta das Nações Unidas, da qual faz parte integrante o anexo Estatuto da Corte Internacional de Justiça, assinada em São Francisco, a 26 de junho de 1945, por ocasião da Conferência de Organização Internacional das Nações Unidas. Disponível em: http:/ / www.planalto.gov.br/ccivil_03/decreto/1930-1949/d19841.htm. Acesso em: 27 fev. 2018.

53 Nesse sentido: BIERRENBACH, Ana Maria. O Conceito de Responsabilidade de Proteger e o Direito Internacional Humanitário. Brasília: Fundação Alexandre Gusmão, 2011. p. 81.

54 ONU. Assembleia Geral. AG Res. 377 (V). 1950.

55 JUBILUT, Liliana Lyra. Não Intervenção e Legitimidade Internacional. São Paulo: Saraiva, 2010. p. 114.

56 RICOBOM, Gisele. Intervencão Humanitária: a guerra em nome que o Princípio da Soberania deve ser visto como uma responsabilidade e não somente como um direito, de modo que, em caso de não cumprimento da obrigação de proteção, há legitimidade para uma intervenção pela ordem internacional.

\subsection{A Soberania como responsabilidade}

Superada a questão quanto à suposta ilegalidade da intervenção por não estar abrangida dentre as competências do Conselho a proteção dos direitos humanos, impositiva a análise de tal proteção frente aos princípios da soberania estatal (art. 2.1 da Carta), protegido pelo princípio da não intervenção (art. 2.7) e proibição do uso da força (art.2.4).

O Princípio da Soberania é aquele que fundamenta a liberdade de um Estado em gerenciar seus assuntos internos e externos. O Princípio da não Intervenção tem como objeto a proteção de tal liberdade. ${ }^{57}$ Seu conceito jurídico desde sempre foi controverso e de difícil precisão, sendo geralmente caracterizado pela independência, autodeterminação, poder de jurisdição ${ }^{58}$ e autoridade de cada estado dentro do seu território, bem como na sua capacidade de estabelecer relações com outros Estados. ${ }^{59}$

A assinatura dos tratados de Westfália (11 tratados cuja assinatura pôs fim a Guerra dos Trinta Anos), também conhecida como Paz de Westfália (1648), é um marco histórico no surgimento do Estado moderno, tendo

dos direitos humanos. Belo Horizonte: Fórum, 2010.

57 VINCENT. No Intervención y Orden Internacional [1]. Chile/ Buenos Aires: Marymar, 1976. p. 19. Disponível em: https://www.maxwell.vrac.puc-rio.br/10564/10564_3.PDF. Acesso em: 13 jan. 2018. 58 A doutrina distingue os poderes de jurisdição estatal em: jurisdição normativa, compulsória e jurisdicional. A primeira refere-se ao poder de cada Estado em disciplinar juridicamente sobre cada matéria; a segunda é relacionada ao poder de exigir o cumprimento das normas, administrativamente ou por meios policias; e a terceira diz respeito ao poder de levar a julgamento e sancionar um sujeito pela prática de alguma infração. Em: MACHADO, Jónatas Eduardo Mendes. Direito Internacional: do paradigma clássico ao pós-11 de setembro. 3. ed. Coimbra: Coimbra, 2006. p. 217.

59 A doutrina distingue os poderes de jurisdição estatal em: jurisdição normativa, compulsória e jurisdicional. A primeira refere-se ao poder de cada Estado em disciplinar juridicamente sobre cada matéria; a segunda é relacionada ao poder de exigir o cumprimento das normas, administrativamente ou por meios policias; e a terceira diz respeito ao poder de levar a julgamento e sancionar um sujeito pela prática de alguma infração. Em: MACHADO, Jónatas Eduardo Mendes. Direito Internacional: do paradigma clássico ao pós-11 de setembro. 3. ed. Coimbra: Coimbra, 2006. p. 213-5. 
marcado o fim das guerras religiosas e sido reconhecida a autoridade soberana dos príncipes, bem como proclamada sua igualdade. Os Estados, a partir de então, passaram a ser considerados igualmente soberanos, estando subordinados a um único direito das gentes. ${ }^{60} \mathrm{Jean}$ Bodin foi o primeiro grande teórico da concepção de soberania. Para ele o poder soberano era absoluto e perpétuo, estando, apenas, limitado pelas leis divinas, leis fundamentais do Estado, leis pertinentes à propriedade privada e pelos pactos firmados entre os súditos. ${ }^{61}$

Grotius, por sua vez, entendia que a soberania era limitada pela lei divina, pelo direito natural e pelo direito das gentes ${ }^{62}$, defendendo uma noção de que a segurança, tanto interna quanto externa, é necessidade vital do indivíduo. Se um estado em conflito não conseguia garantir aos seus cidadãos direitos básicos inerentes à pessoa humana, tais direitos deveriam ser assegurados por uma comunidade internacional. ${ }^{63}$

Dessa forma, percebe-se, desde aquela época, que há uma necessária limitação ao poder do soberano. Não obstante, alguns autores ainda defendem o caráter absoluto do princípio. ${ }^{64}$ São posições que defendem a supremacia da soberania que possibilitaram a ocorrência de atrocidades, lavando as mãos de qualquer responsabilidade perante às vítimas.

Em 1922 um judeu chamado Bernheim compareceu diante da Assembleia apresentando queixa contra práticas nazistas que desrespeitavam a convenção germano-polaca de 1922 (estabelecia a proteção das minorias). Em resposta a tais alegações, o representante da Alemanha teria apenas dito que as práticas internas não diziam respeito aos presentes, diante da soberania estatal. Àquela época, a Assembleia não faz qualquer

60 AMORIM, João Alberto Alves. A ONU e o Meio Ambiente: Direitos humanos, mudanças climáticas e segurança internacional no século XXI. São Paulo: Atlas, 2015. p. 8-9.

61 LATAROLA. Antonio José. Formação histórica do conceito de soberania. In: MIALHE, Jorge Luis (org.). Direito das Relações Internacionais: Ensaios Históricos e Jurídicos. São Paulo: Milennium, 2007. p. 86-7.

62 FRANÇA, Paulo Roberto Caminha de Castilhos. A Guerra do Kosovo, a OTAN e o Conceito de "Intervenção Humanitária". Porto Alegre: Editora da UFGRS, 2004. p. 167.

63 CINELLI, Carlos Frederico. Direito Internacional Humanitário: ética e legitimidade no uso da força em conflitos armados. Curitiba: Juruá, 2016. p. 40.

64 Citamos: RICOBOM, Gisele. Intervenção Humanitária: a guerra em nome dos direitos humanos. Belo Horizonte: Fórum, 2010; JUBILUT, Liliana Lyra. Não Intervenção e Legitimidade Internacional. São Paulo: Saraiva, 2010. condenação, apenas fazendo uma afirmação de que os Estados membros não atentem contra os direitos dos homens sob sua jurisdição. Tal decisão, que considerou absoluto o Princípio da Soberania, de forma a se abster de qualquer responsabilidade internacional, permitiu que Hitler pusesse em prática sua política Mein Kampf. ${ }^{65}$

Assim, ao defender o caráter absoluto do Princípio da Soberania, acaba por se concordar com a inércia diante de atrocidades como aquelas cometidas com os judeus durante a Segunda Guerra Mundial.

Em contrapartida, reconhecendo responsabilidade moral de intervir, há aqueles que entendem ser a soberania limitada, tanto pelo Direito Internacional dos Direitos Humanos como pelo Direito Humanitário, de modo a possibilitar uma atuação da comunidade internacional quando infringidas tais normas. ${ }^{66}$

\section{Betatti afirma que:}

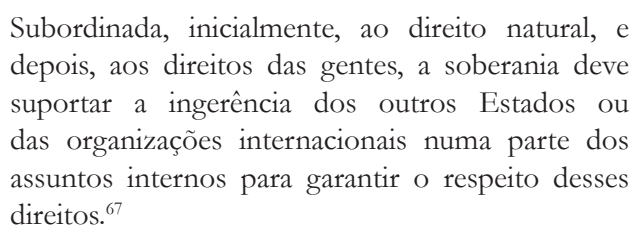

Ituassú distingue soberania interna de soberania externa, afirmando que aquela é absoluta, sendo o Estado "[...] um poder que não depender de ninguém e que não pode ser igualado por nenhum outro", enquanto esta é limitada pelas normas jurídicas de Direito Internacional, e pode ser definida como "[...] a qualidade que tem o Estado de não se obrigar senão por sua própria vontade" ${ }^{98}$, conduzindo a uma ideia de igualdade entre estados. $^{69}$

O autor repugna a possibilidade de existência de uma soberania externa absoluta, sustentando que a necessidade de uma comunidade internacional faz com que os Estados estejam sujeitos a um conjunto de restrições. Nesse sentido reflete:

o direito interno delimita os passos do indivíduo,

65 BETTATI, Mario. O Direito de Ingerência: mutação da ordem internacional. Lisboa: Instituto Piaget, 1996. p. 18-9.

66 BIERRENBACH, Ana Maria. O Conceito de Responsabilidade de Proteger e o Direito Internacional Humanitário. Brasília: Fundação Alexandre Gusmão, 2011. p. 14-5.

67 BETTATI, Mario. O Direito de Ingerência: mutação da ordem internacional. Lisboa: Instituto Piaget, 1996. p. 40.

68 ITUASSÚ, Oyama Cesar. Curso de Direito Internacional Público. Rio de Janeiro: Forense, 1986. p. 199-200.

69 MOREIRA, Adriano. Teoria das Relacõoes Internacionais. 2. ed. Coimbra: Almedina, 1997. p. 410. 
sem lhe retirar a livre disposição e, transposta a noção para o plano exterior, aquele poder individual, que se transferiu para o Estado e se projetou na vida internacional, não lhe dá o caráter supremo. ${ }^{70}$

Conclui que o sistema político interno deve estar em conformidade com o Direito Internacional. Isso, pois, apesar do Direito de Legislação ser exclusivo, não é arbitrário, “[...] devendo atender aos critérios de humanidade, solidariedade internacional contra o delito, respeito ao direito adquirido etc." ${ }^{71} \mathrm{~A}$ responsabilidade primária pela resguarda dos direitos humanos de seus cidadãos é do Estado no qual residem, no entanto, há uma limitação a sua soberania em detrimento à preservação dos direitos do homem, de modo que os problemas internos tendem a se transformar em problemas internacionais (por serem de sua relevância). ${ }^{72}$

Tesón defende que a autonomia estatal advém da autonomia individual dos seus cidadãos, sendo tal autonomia intrínseca com a noção de direitos humanos e inviolabilidade de tais direitos. ${ }^{73}$ Dessa forma, todo ser humano possui direitos decorrentes do fato de ser, simplesmente, humano, não sendo estes decorrentes do Direito Internacional.

O princípio da soberania nunca foi uma licença para que os estados agissem como quisessem, ignorando os direitos fundamentais de seus cidadãos. Soberania deve implicar também responsabilidade, não apenas poder. ${ }^{74}$

É nesse sentido que conclui a Comissão Internacional sobre Intervenção e Soberania dos Estados (sigla em inglês: ICISS):

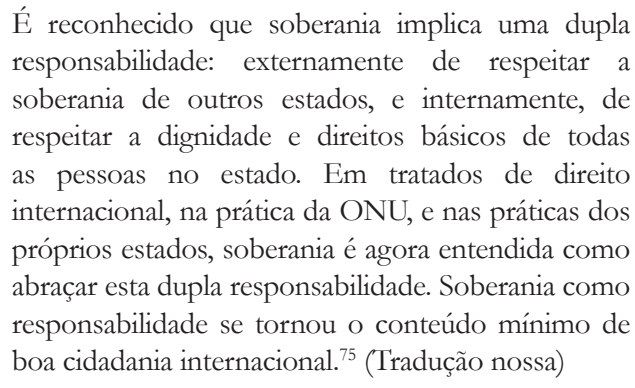

70 ITUASSÚ, Oyama Cesar. Curso de Direito Internacional Público. Rio de Janeiro: Forense, 1986. p. 201.

71 ITUASSÚ, Oyama Cesar. Curso de Direito Internacional Público. Rio de Janeiro: Forense, 1986. p. 208.

72 MOREIRA, Adriano. Teoria das Relações Internacionais. 2. ed. Coimbra: Almedina, 1997. p. 296.

73 TESÓN, Fernando R. Humanitarian Intervention: an inquiry into law and morality. 2. ed. New York: Transnational, 1997. p. 76-7.

74 ANNAN, Kofi A. Intervenções: uma vida de guerra e paz. São Paulo: Companhia das Letras, 2013. p. 112-3.

75 "It is acknowledged that sovereignty implies a dual responsibil-
A própria Carta é um exemplo de obrigação internacional assumida pelos estados membros, que, ao se tornarem membros da Organização, concordam com todas as disposições da Carta, incluindo suas garantias e responsabilidades, dentre as quais: “[...] promover e estimular o respeito aos direitos humanos e às liberdades fundamentais para todos, sem distinção de raça, sexo, língua ou religião". ${ }^{76}$

É nesse sentido que tem sido o entendimento do Conselho de Segurança, da Assembleia Geral, assim como da Corte Internacional de justiça, que já em 1950 afirma que as obrigações emanadas dos artigos 55 e 56 da Carta descartam a possibilidade de alegação de que a proteção dos direitos humanos é de domínio reservado dos Estados (protegido pelo art.2.7 da Carta), considerando a sua salvaguarda como tema de legítimo interesse internacional. ${ }^{77}$

Conforme é exposto pela ICSS, pensar em soberania como responsabilidade implica a (i) responsabilidade das autoridades estatais na proteção da segurança e das vidas dos cidadãos e promoção do seu bem estar; (ii) as autoridades nacionais são responsáveis pelos cidadão internamente e pela comunidade internacional através da ONU; (iii) os agentes do estado são responsáveis e devem ser responsabilizados por suas ações. ${ }^{78}$

O conceito de responsabilidade foi então incorporado ao Documento Final da Cúpula das Nações Unidas em 2005, reconhecendo a responsabilidade primária dos Estados na proteção de seus cidadãos em casos de genocídio, crimes de guerra, limpeza étnica e crimes contra a humanidade, bem como a responsabilidade da comunidade internacional, por meio das Nações Unidas (inclusive pelos meios previstos no Capítulo VII da

ity: externally - to respect the sovereignty of other states, and internally, to respect the dignity and basic rights of all the people within the state. In international human rights covenants, in UN practice, and in state practice itself, sovereignty is now understood as embracing this dual responsibility. Sovereignty as responsibility has become the minimum content of good international citizenship". Em: International Commission on Intervention and State Sovereignty. The Responsibility to Protect. p. 8, dez. 2001. Disponível em: http:// responsibilitytoprotect.org/ICISS\%20Report.pdf. Acesso em: 8 fev. 2018. 76 Art. 1.3 Carta.

77 TRINDADE, Antônio Augusto Cançado. A Proteção Internacional dos Direitos Humanos: Fundamentos jurídicos e instrumentos básicos. São Paulo: Saraiva, 1991. p. 5.

78 International Commission on Intervention and State Sovereignty. The Responsibility to Protect. p. 13, dez. 2001. Disponível em: $<$ http://responsibilitytoprotect.org/ICISS\%20Report.pdf $>$. Acesso em: 8 fev. 2018. 
Carta), em caso de descumprimento da responsabilidade primária. $^{79}$

Assim, resta claro que há responsabilidade contida na soberania, residindo esta, inicialmente, com o estado que tem sua população afetada por graves e sistemáticas violações de direitos humanos. Somente nos casos de ineficácia das medidas tomadas, omissão frente às violações, ou ser o próprio estado o perpetrador das ofensas, deve o Conselho de Segurança tomar uma medida, inclusive coercitiva se necessário. ${ }^{80}$

Dessa forma, não se está a tornar obsoleto o Princípio da Soberania, e, consequentemente, da intervenção e do não uso da força; no entanto, reconhece-se sua limitação em detrimento dos direitos inerentes à pessoa humana, sendo a soberania fonte tanto de deveres como de direitos, estando estes condicionados àqueles. Em outras palavras, o direito das pessoas deve prevalecer sobre o direito dos estados. ${ }^{81}$

Pode-se concluir, portanto, a legalidade da intervenção humanitária quando determinada/autorizada pelo CSNU, com base no capítulo VII da Carta, ou seja, quando a violação de direitos humanos constitua uma ameaça à paz ou segurança internacional (frisando que a intervenção não é fundamentada nos direitos do homem per se, mas na proteção da paz e segurança internacionais, que pode se ver ameaçada devido a grandes violações de direitos fundamentais dos indivíduos), não sendo o art. 42 limitado pelo Princípio da Soberania dos estados ou pelos demais princípios que derivam deste.

A possibilidade que o Conselho autorize a intervenção a bel-prazer tem gerado grandes debates na comunidade internacional a respeito do controle da legalidade de suas resoluções. A seção 3.4 do artigo analisa a possibilidade de revisão das resoluções do órgão.

79 ASSEMBLEIA GERAL DAS NAÇÕES UNIDAS. Resultado da Cupula Mundial de 2005 A/RES/60/1. p. 30, 24 out. 2005. Disponível em: https://undocs.org/A/RES/60/1. Acesso em: 20 mar. 2018.

80 INTERNATIONAL COMMISSION ON INTERVENTION AND STATE SOVEREIGNTY. The Responsibility to Protect p. 17, dez. 2001. Disponível em: http://responsibilitytoprotect.org/ ICISS\%20Report.pdf. Acesso em: 8 fev. 2018.

81 D'AMATO, Anthony A. International Law Studies. 26 fev. 1997. p. 378. Disponível em: https://books.google.com.br/ books?id $=$ uNuYKduz_kAC\&printsec $=$ frontcover\&hl $=$ pt $\mathrm{BR} \&$ source $=$ gbs_ge_summary_r\&cad $=0 \#_{\mathrm{v}}=$ onepage $\& \mathrm{q}=$ interven tion \&f=false. Acesso em: 3 mar. 2018.

\subsection{O controle de legalidade das resoluções do Conselho de Segurança}

Um dos problemas decorrentes da autorização das intervenções humanitárias pelo Conselho é a total discricionariedade que a expressão ampla ameaça à paz, ruptura da paz on ato de agressão (art.39) dá ao órgão de determinar quais situações se encaixam em tais situações. Assim, com base nas diversas decisões tomadas pelo CSNU no período pós-Guerra Fria a respeito do assunto, surge a dúvida se há limites legais para o poder do órgão e quais são esses limites, além de quem os controlaria.

Alguns autores defendem que o controle das atividades do Conselho está na própria aquiescência dos estados-membros de suas decisões. Isso porque, conforme o art. $43^{82}$, o CSNU depende dos estados-membros para o fornecimento de forças armadas, a fim de cumprir o determinado na Resolução (uma vez que não dispõe de força armada própria permanente). Ou seja, os Estados-membros podem sempre contestar as decisões tomadas pelo órgão (mesmo que pelo simples não fornecimento dos meios para cumprimento da Resolução). ${ }^{83}$

No entanto, basta que um Estado-membro forneça o pessoal necessário para o cumprimento da medida (podendo fazê-lo movido por interesses políticos), não se tratando, portanto, necessariamente de um controle

82 "Artigo 43. 1. Todos os Membros das Nações Unidas, a fim de contribuir para a manutenção da paz e da segurança internacionais, se comprometem a proporcionar ao Conselho de Segurança, a seu pedido e de conformidade com o acordo ou acordos especiais, forças armadas, assistência e facilidades, inclusive direitos de passagem, necessários à manutenção da paz e da segurança internacionais. 2. Tal acordo ou tais acordos determinarão o número e tipo das forças, seu grau de preparação e sua localização geral, bem como a natureza das facilidades e da assistência a serem proporcionadas. 3. O acordo ou acordos serão negociados o mais cedo possível, por iniciativa do Conselho de Segurança. Serão concluídos entre o Conselho de Segurança e Membros da Organização ou entre o Conselho de Segurança e grupos de Membros e submetidos à ratificação, pelos Estados signatários, de conformidade com seus respectivos processos constitucionais." (Grifo nosso). BRASIL. Decreto no 19.841, de 22 de outubro de 1945. Promulga a Carta das Nações Unidas, da qual faz parte integrante o anexo Estatuto da Corte Internacional de Justiça, assinada em São Francisco, a 26 de junho de 1945, por ocasião da Conferência de Organização Internacional das Nações Unidas. Disponível em: <http://www.planalto.gov.br/ccivil_03/decreto/1930-1949/ d19841.htm>. Acesso em: 12 abr. 2018.

83 RAJCIC, Ivana. Legal Control over Decisions Taken by the United Nations Orgarns and Judicial Review of the Security Council Decisions. Pravnik, v. 48, n. 1, 2014. p. 112. Disponível em: https:// hrcak.srce.hr/file/216771. Acesso em: 12 abr. 2018. 
de legalidade efetivo.

Surge, então, o debate acerca da possibilidade de revisão judicial das Resoluções do Conselho pela Corte Internacional de Justiça, que advém da problemática de conflito entre as decisões da Corte - que tem competência para "todas as questões que as partes lhe submetam, bem como todos os assuntos especialmente previstos na Carta das Nações Unidas ou em tratados e convenções em vigor" ${ }^{\prime \prime 4}$ - e do CSNU, a quem é incumbido o processamento da responsabilidade estatal no âmbito da imposição das sanções coletivas. ${ }^{85}$

A discussão emerge, principalmente, de dois casos: o caso Bósnia e o caso Lokerbie. No primeiro (Bósnia e Herzegovina vs. Iugoslávia), a Bósnia solicitou que a Resolução $713^{86}$, de 1991, que estabeleceu um embargo de armas para a região, deve ser "[...] interpretada de uma maneira que não impeça o direito inerente de defesa individual ou coletiva da Bósnia e Herzegovina nos termos do artigo 51 da Carta das Nações Unidas e as regras costumeiras de Direito Internacional [...]".87 (Tradução nossa). Todavia, nesse caso, considerando o pedido de proteção de direitos fundamentais da pessoa humana especificados na Declaração Universal de Direitos do Homem, a Corte entendeu que o pedido fugia de sua jurisdição, uma vez que a base da jurisdição do órgão é a Convenção para a Prevenção e punição ao crime de genocídio, não analisando o conteúdo da Resolução do CSNU; o juiz ad hoc Leuterpacht, em voto vencido, afirmou que a Corte poderia ter declarado o

84 Artigo 36. ONUBR. Organizações Unidas no Brasil. Estatuto da Corte Internacional de Justiça. Disponível em: https:// nacoesunidas. org/carta/cij/. Acesso em: 02 maio 2018.

85 RAMOS, André de Carvalho. Processo Internacional de Direitos Humanos: análise dos sistemas de apuração de violações de direitos humanos e implementação das decisões no Brasil. Rio de Janeiro: Renovar, 2002. p. 179.

86 " 6 . Decides, under Chapter VII of the Chart of United Nations that all States shall, for the purposes of establishing peace and stability in Yugoslavia, immediately implement a general and complete embargo on all deliveries of weapons and military equipment to Yugoslavia until the Council decides otherwise following consultation between the Secretary-General and the Government of Yugoslavia.” p. 43. Disponível em: http://www.un.org/en/ga/search/ view_doc.asp?symbol=S/RES/713(1991). Acesso em: 20 abr. 2018. 87 " $(\mathrm{m})[. .$.$] must be construed in a manner that shall not impair the$ inherent right of individual or collective self-defence of Bosnia and Herzegovina under the terms of Article 51 of the Charter of the United Nations and the rules of customary international law; [...]". BEDJAOUI, Mohammed. President of the International Court of Justice The Hague, p. 24, 9 ago. 1994. Disponível em: http://www. icj-cij.org/files/annual-reports/1993-1994-en.pdf. Acesso em: 20 abr. 2018. conflito entre tal resolução e o jus cogens, a fim de que o próprio Conselho reconsiderasse sua decisão. ${ }^{88}$

Já no caso Lokerbie, foi levantado o conflito de competência entre a Corte e o Conselho diante da resolução 731 (1992) e, posteriormente, da resolução 748 (1992). A Líbia argumentou que a resolução 731 ia de encontro a todo o procedimento para a solução pacífica de conflitos, prevista na Convenção de Montreal; enquanto os Estados Unidos argumentaram que, apesar da jurisdição dos dois órgãos ser paralela, assuntos que dizem respeito à apreciação política, são de competência exclusiva do Conselho. ${ }^{89}$ Apesar de não ter apreciado de fato a legalidade da decisão do Conselho de Segurança, a Corte não o fez, pois entendeu que a questão seria de mérito, não devendo ser apreciada no âmbito da medida cautelar, mas não porque não tivesse competência para apreciá-la. Nesse sentido, a contribuição da decisão do Juiz Weeramantry foi importante. Esta, apesar de reconhecer que a Corte não pode funcionar como um tribunal de apelação no sistema das Nações Unidas, sustenta que a Corte deve assumir seu papel como principal órgão judicial da organização, devendo agir como guardiã da Carta e do Direito Internacional, não havendo

[...] órgão superior incumbido com funções judiciais e com a determinação de interpretação das questões e aplicação da lei internacional. [...] o fato de que a decisão judicial baseada na lei pode ter consequências políticas não é um fator que iria desviar (a Corte) do cumprimento das suas obrigações nos termos da Carta das Nações Unidas e do Estatuto da Corte..$^{90}$ (Tradução nossa).

A Corte estabeleceu, então, presunção de validade da Resolução 748, o que pode ser "um indício de um controle judicial moderado das resoluções do Conselho

88 RAMOS, André de Carvalho. Processo Internacional de Direitos Humanos: análise dos sistemas de apuração de violações de direitos humanos e implementação das decisões no Brasil. Rio de Janeiro: Renovar, 2002. p. 181.

89 DISSENTING opinion of Judge Weeramantry. Montreal Convention (DISS. OP. WEERAMANTRY). 1971. p. 55. Disponível em: http://www.icj-cij.org/files/case-related/88/088-19920414-ORD01-07-EN.pdf. Acesso em: 20 abr. 2018.

90 " [...] there is no higher body charged with judicial functions and with the determination of questions of interpretation and application of international law. [...] the fact that its judicial decision based upon the law may have political consequences is not a factor that would deflect it from discharging its duties under the Charter of the United Nations and the Statute of the Court." DISSENTING opinion of Judge Weeramantry. Montreal Convention (DISS. OP. WEERAMANTRY). 1971. p. 57. Disponível em: http://www.icjcij.org/files/case-related/88/088-19920414-ORD-01-07-EN.pdf. Acesso em: 20 abr. 2018. 
de Segurança". ${ }^{91}$ Não obstante, ainda se trata de tema pouco explorado, não havendo muitos casos em que surge tal controvérsia apresentados perante a Corte. $\mathrm{O}$ Conselho continua, a princípio, como órgão autônomo da ONU, não estando sujeito ao controle de legalidade de nenhum outro órgão. Apesar disso, espera-se que, com a apresentação de novos casos à Corte Internacional de Justiça, esta faça valer sua condição de órgão judicial máximo da ONU (conforme art. $92^{92}$ ), bem como sua competência, ainda que esses fatos já tenham sido apreciados pelo Conselho de Segurança; ou seja, tratar-se-ia de um controle a posteriori caso a ação fosse ilegal, o que daria margem a uma reparação ao estado lesado. ${ }^{93}$

\section{A QUeSTÃo dA LEGITIMIDADE}

Conforme afirmamos acima, a intervenção humanitária será considerada legal sempre que autorizada/ determinada pelo Conselho de Segurança em casos de tamanha violação de direitos humanos que se caracteriza ameaça à paz e à segurança internacional. Atualmente, não há um órgão encarregado de controlar a legalidade dessas decisões. No entanto, não há requisitos objetivos na Carta das Nações Unidas de modo que há total discricionariedade do CSNU na determinação da intervenção.

Considerando-se que, atualmente, está superado o modelo positivista — não sendo a legitimidade esgotada no plano do direito _ - a moral e a lei devem estar interligadas. ${ }^{94}$

Buscar-se-á discutir o que constituirá uma decisão legítima que autoriza/determina a intervenção militar, ou, ainda, se é possível que uma intervenção seja legí-

91 RAMOS, André de Carvalho. Processo Internacional de Direitos Humanos: análise dos sistemas de apuração de violações de direitos humanos e implementação das decisões no Brasil. Rio de Janeiro: Renovar, 2002. p. 182.

92 “Artigo 92. A Corte Internacional de Justiça será o principal órgão judiciário das Nações Unidas. [...]”. (Grifo nosso). BRASIL. Decreto $n^{\circ}$ 19.841, de 22 de outubro de 1945. Promulga a Carta das Nações Unidas, da qual faz parte integrante o anexo Estatuto da Corte Internacional de Justiça, assinada em São Francisco, a 26 de junho de 1945, por ocasião da Conferência de Organização Internacional das Nações Unidas. Disponível em: http://www.planalto.gov.br/ccivil_03/decreto/1930-1949/d19841.htm. Acesso em: 20 abr. 2018.

93 MELLO, Celso D. De Albuquerque. Curso de Direito Internacional Público. Rio de Janeiro: Renovar, 2001. p. 618. v. 1

94 TESÓN, Fernando R. Humanitarian Intervention: an inquiry into law and morality. 2. ed. New York: Transnational, 1997. p. ix. tima sem que tenha sido autorizada/determinada pelo órgão legal competente: o CSNU. Tal legitimidade é denominada por Juliana Jubilut como legitimidade normativa: aquela que

[...]avalia tanto a coadunação das normas com a tríade normativa legalidade-moralidadeconstitucionalidade, verificando-se por meio dessa a adequação de seu conteúdo aos demais valores do cenário internacional, quanto a validade formal das normas por meio da análise do processo pelo qual a norma foi estabelecida. ${ }^{95}$

A palavra legitimidade advém do latim, legitimus, que significava legal: de acordo com a lei. ${ }^{96}$ A legitimidade que tem como base apenas a letra pura da lei era a visão defendida por Kelsen. Para o filósofo, tudo que é legal é também legítimo ${ }^{97}$; enquanto Bobbio, por sua vez, refere que legitimidade remete "[...] ao grau de consenso numa parcela significativa da população capaz de garantir a obediência sem necessidade de recorrer à força". ${ }^{98}$

Já Habermas entende que o direito, a política e a moral estão entrelaçados..$^{99} \mathrm{Da}$ mesma forma, Tesón entende que a moral e lei estão interligadas, afirmando que a lei "[...] flutua em um mar de moralidade, e mesmo que o vaso legal seja distinto da água em que está imerso, não se pode começar a explicar a forma ou o propósito do vaso sem fazer qualquer referência à água". ${ }^{100}$ (Tradução nossa). Ou seja, atualmente a legalidade não se esgota na legitimidade, podendo uma intervenção ser legítima e ilegal; e ilegal e ilegítima.

Ao tratar da legitimidade da intervenção humanitária, esta deverá ser analisada em três momentos: no momento em que é determinada/autorizada; em seu meio, pelos meios que estão sendo utilizados para executar

95 JUBILUT, Liliana Lyra. Não Intervenção e Legitimidade Internacional. São Paulo: Saraiva, 2010. p. 82.

96 MOREIRA, Felipe Kern. Direito e Legitimidade na Sociedade Internacional. Boa Vista: Editora da Universidade Federal de Roraima, 2012. p. 23.

97 MOREIRA, Felipe Kern. Direito e Legitimidade na Sociedade Internacional. Boa Vista: Editora da Universidade Federal de Roraima, 2012. p. $17-63$

98 BOBBIO, Norberto. Dicionário de Política. In: MOREIRA, Felipe Kern. Direito e Legitimidade na Sociedade Internacional. Boa Vista: Editora da Universidade Federal de Roraima, 2012. p. 60.

99 HABERMAS, Jürgen. Direito e Moral. Lisboa: Instituto Piaget, 1999. p. 87-8.

100 "Law floats upon a sea of morality, and even though the legal vessel is distinct from the water in which it is immersed, one could not begin to explain the shape or purpose of the vessel without making any reference to water." TESÓN, Fernando R. Humanitarian Intervention: an inquiry into law and morality. 2. ed. New York: Transnational, 1997. p. ix. 
a intervenção; e, por fim, ao seu final, analisando se o objetivo inicialmente estabelecido foi cumprido. Será considerada legítima a intervenção na qual puder se verificar a soma dessas legitimidades.

Para entendermos quando uma decisão que determina a intervenção será legítima, temos de refletir sobre o porquê da norma que possibilita tal medida. Qual era seu propósito?

Conforme afirmado anteriormente, a intervenção tem como objetivo salvaguardar a paz e segurança internacionais, buscando não tornar a Carta das Nações Unidas obsoleta e garantido à organização um recurso legítimo ao qual possa recorrer em casos de descumprimento por algum Estado-membro de tudo o que a Carta busca proteger. O documento chega a ser referido por alguns autores como uma constituição internacional, determinando valores comuns e princípios guiadores, sendo um verdadeiro mínimo valorativo comum da comunidade internacional. ${ }^{101}$

Dessa forma, a legitimidade da intervenção estará ligada, conforme anteriormente exposto, a uma consciência moral da humanidade, expressa pelos valores contidos na Carta. ${ }^{102}$ Ana Maria Bierrenbach afirma que "o que dá ao poder legitimidade é o fato de agir em nome de normas reconhecidas como universais e, dessa forma, preservar valores e instituições que sirvam a todos". ${ }^{103}$

Atualmente, o Direito, assim como o Estado, estão voltados ao indivíduo, encontrando, na dignidade da pessoa humana e nos direitos humanos, a sua noção de justiça. Dessa forma, é o respeito ao próprio ser humano que deve guiar todas as condutas, tanto humanas quanto institucionais ou estatais, e é quando uma não observância à dignidade do ser humano (fundamento central dos direitos humanos ${ }^{104}$ ) se apresenta, que a intervenção se faz necessária. ${ }^{105}$

101 JUBILUT, Liliana Lyra. Não Intervenção e Legitimidade Internacional. São Paulo: Saraiva, 2010. p. 84.

102 WALZER, Michael. Guerras Justas e Injustas: uma argumentação moral com exemplos históricos. São Paulo: Martins Fontes, 2003. p. 183.

103 BIERRENBACH, Ana Maria. O Conceito de Responsabilidade de Proteger e o Direito Internacional Humanitário. Brasília: Fundação Alexandre Gusmão, 2011. p. 45.

104 CAVALIERI FILHO, Sérgio. Programa de Responsabilidade Civil. 12. ed. Rio de Janeiro: Grupo GEN, 2015. p. 118.

105 JUBILUT, Liliana Lyra. Não Intervenção e Legitimidade Internacional. São Paulo: Saraiva, 2010. p. 73.
Tal ideia está interligada à noção de normas jus cogens, ou seja, aquelas normas de caráter tão essencial que são consideradas inderrogáveis, não estando sujeitas à vontade de quem quer que seja. Nem todas as normas de direitos humanos são jus cogens, apenas os direitos humanos básicos, ou seja, quando a violação da dignidade do ser humano é latente. ${ }^{106}$

As normas jus cogens são normas cujas violações, pode-se afirmar, ferem a moralidade universal, uma vez que as normas desse gênero decorrem de "[...] uma aproximação entre as normas costumeiras e os imperativos morais internacionais[...]", remetendo a uma noção de justiça universal. ${ }^{107}$

Assim, no primeiro pilar da análise da legitimidade, entendemos que será legítima a intervenção que tiver por fundamento a violação a uma norma de jus cogens.

A necessidade da análise dos meios utilizados advém de que a intervenção nunca pode causar mais malefícios do que os benefícios que traz, devendo sua atuação seguir as normas de direito humanitário, uma vez que é esse o ramo do Direito Internacional que traz a estrutura normativa que estipula os direitos e deveres em conflitos armados. ${ }^{108}$

Patriota afirma que o processo de prática das intervenções humanitárias se autolegitima não pela sua consistência jurídica, mas pelo seu significado político: “[...] do impacto mais ou menos positivo que tiver sobre a situação do terreno e de sua repercussão nas relações internacionais". ${ }^{109}$ Dessa forma, no segundo pilar, será legítima a intervenção que, na sua execução, obedecer às normas de Direito Internacional Humanitário.

Por fim, o último pilar da análise da legitimidade se dará no momento em que cessar as causas estabelecidas como justificativas para a intervenção (primeiro pilar). Não pode, portanto, a intervenção continuar quando as graves violações de direito humanos tiverem cessado. ${ }^{110}$

106 DAUDT, Gabriel Pithan. Reservas aos Tratados Internacionais de Direitos Humanos: o conflito entre a eficácia e a promoção dos direitos humanos. Porto Alegre: Sergio Antonio Fabris, 2006. p. 149-54. 107 DAUDT, Gabriel Pithan. Reservas aos Tratados Internacionais de Direitos Humanos: o conflito entre a eficácia e a promoção dos direitos humanos. Porto Alegre: Sergio Antonio Fabris, 2006. p. 155. 108 JUBILUT, Liliana Lyra. Não Intervenção e Legitimidade Internacional. São Paulo: Saraiva, 2010. p. 152.

109 PATRIOTA, Antonio de Aguiar. O Conselho de Segurança após a Guerra do Golfo: a articulação de um novo paradigma de segurança coletiva. Brasília: Instituto Rio Branco, 1998. p. 118.

110 International Commission on Intervention and State Sovereignty. The Responsibility to Protect. p. 37, dez. 2001. Disponível em: 
Assim, a análise da legitimidade deve ser feita nesses três momentos, não sendo a legitimidade e a legalidade dependentes, devendo o parecer destas ser feita de forma autônoma. Desse modo, uma intervenção poderá ser ilegítima, mas legal; bem como legítima, mas ilegal (quando não for determinada/autorizada pelo Conselho de Segurança).

A ONU vem agindo para definir elementos objetivos que legitimem a intervenção, sendo o Relatório intitulado $A$ Responsabilidade de Proteger (Responsability to Protect, ou, R2P, sigla em inglês), um dos resultados de tais esforços.

\subsection{A Legitimidade a partir dos critérios estabelecidos pela Comissão Internacional sobre Intervenção e Soberania dos Estados: a Responsabilidade de Proteger}

A Comissão Internacional sobre Intervenção e Soberania dos Estados foi constituída após o discurso do então Secretário-Geral da ONU, Kofi Annan, em 1999, o qual declarou a possibilidade da intervenção por parte da comunidade internacional quando constatadas violações flagrantes, sistemáticas e generalizadas de direitos humanos, lançando a problemática da intervenção humanitária, exigindo maior definição para o tema dentro das Nações Unidas. ${ }^{111}$

Assim, a ICISS buscou estabelecer os critérios essenciais para que fosse possível a autorização de uma intervenção por parte do CSNU, sendo o relatório denominado $A$ Responsabilidade de Proteger ${ }^{122}$, resultado de tal trabalho.

O título do relatório é considerado uma reformulação do conceito de intervenção humanitária, de modo a acabar com a discussão se a intervenção se trata de um direito ou um dever, estabelecendo a existência de uma responsabilidade de proteção, que consiste em uma obrigação moral, sendo detentora de legalidade quando determinada pelo CSNU. ${ }^{113}$

http://responsibilitytoprotect.org/ICISS\%20Report.pdf. Acesso em: 8 fev. 2018.

111 RICOBOM, Gisele. Intervenção humanitária: a guerra em nome dos direitos humanos. Belo Horizonte: Fórum, 2010. p. 220.

112 International Commission on Intervention and State Sovereignty. The Responsibility to Protect. dez. 2001. Disponível em: http:// responsibilitytoprotect.org/ICISS\%20Report.pdf. Acesso em: 8 fev. 2018.

113 ANNAN, Kofi A. Intervenções: uma vida de guerra e paz. São Paulo: Companhia das Letras, 2013. p. 149.
A ICISS estabelece seis critérios para que o Conselho de Segurança possa autorizar uma intervenção humanitária: (i) justa causa, cujas condições são perda de vidas em grande escala ou limpeza étnica em grande escala; (ii) intenção correta; (iii) último recurso; (iv) meios proporcionais; (v) razoáveis chances de sucesso; (vi) autoridade correta. Além de seis princípios operacionais a serem seguidos: (i) objetivos claros; (ii) abordagem militar comum entre parceiros envolvidos; (iii) aceitação de limitações, incrementalismo e gradualismo na aplicação da força; (iv) regras precisas de atuação, que reflitam o princípio da proporcionalidade e envolvam total aderência à lei internacional humanitária; (v) aceitação de que a proteção forçada não pode se tornar o principal objetivo; (vi) máxima coordenação possível com organizações humanitárias. ${ }^{114}$

Passaremos a uma análise pormenorizada dos critérios necessários para autorizar a intervenção, consideraremos legítima uma intervenção quando tais requisitos estiverem preenchidos.

\subsubsection{A justa causa}

O critério da justa causa busca estabelecer que tipo de violação é suficientemente gravosa de forma a mitigar o princípio da soberania estatal, legitimando a intervenção humanitária. O relatório afirma que a medida somente seria justificável em situações que chocassem a consciência da humanidade, traz rol exemplificativo de quais situações se adequariam a essa denominação. ${ }^{115}$

A ICISS define duas situações como suficientemente gravosas, de forma a possibilitar a determinação/autorização da intervenção militar: (i) perda de vidas em grande escala, que não precisa ter intento genocida e (ii) limpeza étnica em grande escala, levada a cabo mediante assassinato, expulsão forçada, ato de terror ou estupro. Em ambos os casos a intenção pode advir do próprio Estado ou por negligência ou falha deste em evitar sua ocorrência. Ainda, não há necessidade de que o Conselho aguarde o acontecimento dos fatos para agir, se

114 International Commission on Intervention and State Sovereignty. The Responsibility to Protect. p. XII-XIII-4, dez. 2001. Disponível em: http://responsibilitytoprotect.org/ICISS\%20Report. pdf. Acesso em: 8 fev. 2018.

115 International Commission on Intervention and State Sovereignty. The Responsibility to Protect. p. 32-4, dez. 2001. Disponível em: http://responsibilitytoprotect.org/ICISS\%20Report.pdf. Acesso em: 8 fev. 2018. 
houver evidência suficiente de que as violações ocorrerão, poderá intervir (intervenção antecipatória). ${ }^{116}$

A Comissão buscou esclarecer as situações que estariam abrangidas nestas duas possibilidades, elencando:

\begin{abstract}
1- Ações definidas pela estrutura da Convenção do Genocídio de 1948 que envolvam ameaça ou perda de vidas em grande escala; 2- a ameaça ou ocorrência de perda de vida em grande escala, quer seja produto de intento genocida ou não, e que envolva ou não a ação estatal; 3- diferentes manifestações de "limpeza étnica", incluindo matança sistemática de membros de um grupo particular a fim de diminuir ou eliminar sua presença em uma área em particular, a remoção física sistemática de membros de um grupo em particular de uma área geográfica em particular, atos de terror designados a fazer com que as pessoas fujam, e estupros sistemáticos com propósitos políticos em mulheres de um determinado grupo (tanto como outra forma de terrorismo, como meio de mudar a composição étnica daquele grupo); 4- crimes contra a humanidade e violações de crimes de guerra, conforme definidos pela Convenção de Genebra, Protocolos Adicional, ou outro lugar, que envolvam matança ou limpeza étnica em larga escala; 5situações de colapso estatal como resultado da exposição da população à fome extrema e/ou guerra civil; 6- grandes catástrofes naturais ou ambientais, onde o Estado em questão é incapaz ou negligente em lidar, ou ligar para assistência, e significante perda de vidas está ocorrendo ou em ameaça. ${ }^{117}$ (Tradução nossa).
\end{abstract}

116 International Commission on Intervention and State Sovereignty. The Responsibility to Protect. p. 31, dez. 2001. Disponível em: http://responsibilitytoprotect.org/ICISS\%20Report.pdf. Acesso em: 8 fev. 2018.

117 "those actions defined by the framework of the 1948 Genocide Convention that involve large scale threatened or actual loss of life; $\square$ the threat or occurrence of large scale loss of life, whether the product of genocidal intent or not, and whether or not involving state action; $\square$ different manifestations of "ethnic cleansing," including the systematic killing of members of a particular group in order to diminish or eliminate their presence in a particular area; the systematic physical removal of members of a particular group from a particular geographical area; acts of terror designed to force people to flee; and the systematic rape for political purposes of women of a particular group (either as another form of terrorism, or as a means of changing the ethnic composition of that group); $\square$ those crimes against humanity and violations of the laws of war, as defined in the Geneva Conventions and Additional Protocols and elsewhere, which involve large scale killing or ethnic cleansing; $\square$ situations of state collapse and the resultant exposure of the population to mass starvation and/or civil war; and $\square$ overwhelming natural or environmental catastrophes, where the state concerned is either unwilling or unable to cope, or call for assistance, and significant loss of life is occurring or threatened." Em: International Commission on Intervention and State Sovereignty. The Responsibility to Protect. p. 33, dez. 2001. Disponível em: http://responsibilitytoprotect.org/ ICISS\%20Report.pdf. Acesso em: 8 fev. 2018.
O relatório busca especificar melhor o que abrange a denominada grave violação dos direitos humanos; no entanto, não específica que grau de matança é uma matança sistemática, o número de pessoas que devem ser forçadas a sair/sofrer violações para ser considerada uma limpeza étnica, ou, ainda, o que constitui grande escala. Dessa forma, percebe-se a impossibilidade de uma determinação de critérios objetivos específicos a fim de definir o que constitui uma grave violação de direitos humanos, restando ao Conselho de Segurança analisar caso a caso quando há necessidade da intervenção e se a gravidade das violações tem força suficiente para chocar a moral da bumanidade.

Em contrapartida, a ICISS expõe situações que não se enquadram na hipótese da causa justa, quais sejam: casos sistemáticos de discriminação racial, aprisionamento ou formas de repressão política, ou mesmo episódios de governos democráticos destituídos por golpes militares. A proteção do nacional no exterior foi excluída do critério, uma vez que estaria regulada pelo art. 51 da Carta. ${ }^{118}$ Assim, a Comissão, ao expor, especificamente, que tais causas não constituem fundamentação legítima para a intervenção humanitária, afasta a possibilidade do intervencionismo amplo.

Isso se dá porque a intervenção não deve ser baseada na proteção dos direitos do homem per se, mas na proteção da paz e segurança internacionais, conforme dispõe o texto literal do art. 42 da Carta, o CSNU goza de uma ampla discricionariedade na avaliação dos pressupostos, uma vez que não há explicitação na Carta do que compõem esses conceitos. ${ }^{119}$

As situações que possibilitam a intervenção humanitária elencadas pela Comissão não são limites absolutos à atuação do CSNU, que deve agir em situações de grande necessidade humanitária, que choquem a consciência da humanidade, sendo, portanto, adotado o posicionamento do intervencionismo limitado: que possibilita a intervenção em casos de extrema violação dos direitos do indivíduo, cabendo ao CSNU, órgão competente originário, determinar, caso a caso, se a situação em análise se enquadra em tal denominação.

118 International Commission on Intervention and State Sovereignty. The Responsibility to Protect. p. 34, dez. 2001. Disponível em: http://responsibilitytoprotect.org/ICISS\%20Report.pdf. Acesso em: 8 fev. 2018.

119 Nesse sentido: MELLO, Celso D. De Albuquerque. Curso de Direito Internacional Público. Rio de Janeiro: Renovar, 2001. p. 473. v. 1 


\subsubsection{A intenção correta}

A intenção da intervenção deve ser a cessão dos atos que ameaçam a paz e segurança internacionais, pondo fim ao sofrimento humano. Em outras palavras: a intenção correta é aquela que tem um fim humanitário. No entanto, a Carta faculta que o termo ameaça à paz seja aquilo que o Conselho julgar, sem que haja limites impostos à atuação do órgão em tais casos. ${ }^{120}$ Esse requisito está ligado também ao respeito pela imparcialidade ${ }^{121}$, de modo que a operação não pode se posicionar a favor ou contra eventuais reivindicações ou posições das partes no conflito, tendo como único objetivo a cessão da grave violação aos direitos dos indivíduos. ${ }^{122}$

A Comissão reconhece que as intervenções de caráter puramente humanitário dificilmente acontecem, mesmo aquelas autorizadas pelo Conselho, diante do “[...] custo orçamentário e risco para o pessoal envolvido em qualquer ação militar podem tornar politicamente indispensável que o Estado interventor tenha condições de alegar alguma forma de interesse na intervenção, não importando quão altruísta o motivo principal seja". ${ }^{123}$ (Tradução nossa). O interesse pode estar, inclusive, ligado à preocupação de evitar uma crise de refugiados, ou alguma outra razão que, mesmo não tendo fundamentação altruísta, não desconfigura o caráter humanitário da intervenção. ${ }^{124}$

120 Nesse sentido: FRANÇA, Paulo Roberto Caminha de Castilhos. A Guerra do Kosovo, a OTAN e o Conceito de "Intervenção Humanitária”. Porto Alegre: Editora da UFGRS, 2004. p. 150.

121 O Brahimi Report trouxe recomendações acerca da diferenciação do princípio da neutralidade ao da imparcialidade. A ONU não deve ser neutra, no sentido de se omitir, mas sim imparcial, o que significa tão somente não favorecer a nenhuma das partes. ASSEMBLEIA GERAL DAS NAÇÕES UNIDAS. Conselho de Segurança. A/55/305-S/2000/809. 21 ago. 2000. Disponível em: <http:// www.un.org/en/ga/search/view_doc.asp?symbol=A/55/305>. Acesso em: 27 abr. 2018.

122 PINTO, Maria do Céu. As Nações Unidas e a Manutenção da Paz: e as actividades de peacekeeping doutras organizações internacionais. Coimbra: Almedina, 2007. p. 137.

123 " [...] the budgetary cost and risk to personnel involved in any military action may in fact make it politically imperative for the intervening state to be able to claim some degree of self-interest in the intervention, however altruistic its primary motive might actually be." International Commission on Intervention and State Sovereignty. The Responsibility to Protect. p. 36, dez. 2001. Disponível em: http://responsibilitytoprotect.org/ICISS\%20Report.pdf. Acesso em: 17 abr. 2018.

124 International Commission on Intervention and State Sovereignty. The Responsibility to Protect. p. 36, dez. 2001. Disponível em: http://responsibilitytoprotect.org/ICISS\%20Report.pdf. Acesso em: 17 abr. 2018.
Nesse sentido, Michael Walzer argumenta que não se pode contar com a vontade pura dos agentes políticos, não devendo as intervenções dependerem de uma pureza moral para ser justa. Defende a possibilidade da intervenção unilateral, expondo que, mesmo que as razões da intervenção não sejam totalmente altruístas, esta estará revestida de legitimidade quando também estiver presente o argumento humanitário, ou seja, quando as violações de direitos humanos sejam tão graves que choquem a consciência moral da humanidade, gerando um direito de intervenção. ${ }^{125}$

Como meio de satisfazer o critério da intenção correta, o relatório apresenta algumas soluções: (i) que a intervenção militar sempre seja coletiva ou multilateral, ao invés de ser conduzida por apenas um país; (ii) analisar até que ponto (e se) a intervenção é apoiada pelos cidadãos que supostamente se beneficiaram desta; (iii) até que ponto a opinião de outros países da região afetada apoiam a intervenção. ${ }^{126}$ No entanto não traz solução para como seria averiguada a vontade da população vítima. ${ }^{127}$

Ainda, para países que apenas levam em consideração o seu melhor interesse, a Comissão explicitou:

[...]a melhor resposta curta deve ser que, hoje em dia, boa cidadania internacional é uma questão de interesse nacional. Com o mundo tão perto e interdependente como é agora, e com crises "em países distantes do qual sabemos pouco" tão capazes como são agora de gerar grandes problemas em outras localidades (com crises de refugiados, pandemias de saúde, terrorismo, tráfico de narcóticos, crime organizado e semelhantes), é altamente discutível que está no melhor interesse de todos os países cooperar para a resolução de tais problemas, além do imperativo humanitário de fazê-lo. ${ }^{128}$ (Tradução nossa).

125 WALZER, Michael. Guerras Justas e Injustas: uma argumentação moral com exemplos históricos. São Paulo: Martins Fontes, 2003. p. XVI-XVII.

126 International Commission on Intervention and State Sovereignty. The Responsibility to Protect. p. 36, dez. 2001. Disponível em: http://responsibilitytoprotect.org/ICISS\%20Report.pdf. Acesso em: 8 fev. 2018.

127 Para uma análise detalhada acerca do monitoramento dos tratados de direitos humanos, ver: The Future of UN Human Rights Treaty Monitoring. Cambridge: Cambridge University Press, 2000.

128 "[...] the best short answer may be that, these days, good international citizenship is a matter of national self-interest. With the world as close and interdependent as it now is, and with crises in "faraway countries of which we know little" as capable as they now are of generating major problems elsewhere (with refugee outflows, health pandemics, terrorism, narcotics trafficking, organized crime and the like), it is strongly arguable that it is in every country's inter- 
Ressalta-se que, em conjunto com o objetivo imediato da intervenção, a força interventora deve ter um propósito em longo prazo para o conflito, uma vez que o objetivo final será sempre a consolidação da paz. No entanto, uma vez cessado o caráter de urgência da intervenção, estando controlada a situação, deve-se cessar o uso da força, evoluindo-se para outros meios de manutenção da paz alcançada. ${ }^{129}$

\subsubsection{0 último recurso}

Ainda, para ser legítima, a intervenção deve ser o último recurso possível dentre os disponíveis pelo CSNU. Assim, antes da imposição da paz (peace enforcement ou responsabilidade de reagir, como denominada pelo relatório $)^{130}$, por meio da intervenção humanitária, devem ser esgotadas as ações de peacemaking e peacekeeping, que constituem a responsabilidade de prevenir. ${ }^{131}$

O peacemaking (restabelecimento da paz) “[...]é a ação para trazer partes hostis a um acordo, essencialmente através de meios pacíficos como aqueles previstos no Capítulo VI da Carta das Nações Unidas". ${ }^{132}$ (Tradução nossa).

\section{Já o Peacekeeping (manutenção da paz) é:}

[...] o desenvolvimento da presença das Nações Unidas no campo, com o consentimento das partes envolvidas, normalmente envolvendo unidades militares e/ou policiais das Nações Unidas e frequentemente civis também. Peacekeeping é uma técnica que expande as possibilidades tanto para

est to contribute cooperatively to the resolution of such problems, quite apart from the humanitarian imperative to do so." International Commission on Intervention and State Sovereignty. The Responsibility to Protect. p. 36, dez. 2001. Disponível em: http:/ / responsibilitytoprotect.org/ICISS\%20Report.pdf. Acesso em: 17 abr. 2018. 129 O DEBATE conceitual sobre intervenção humanitária. p. 75. Disponível em: https://www.maxwell.vrac.puc-rio. br/10564/10564_4.PDF. Acesso em: 3 maio 2018.

130 International Commission on Intervention and State Sovereignty. The Responsibility to Protect. p. 36, dez. 2001. Disponível em: http://responsibilitytoprotect.org/ICISS\%20Report.pdf. Acesso em: 8 fev. 2018.

131 International Commission on Intervention and State Sovereignty. The Responsibility to Protect. p. 19-23, dez. 2001. Disponível em: <http:// responsibilitytoprotect.org/ICISS\%20Report.pdf>. Acesso em: 8 fev. 2018.

132 "[...]is action to bring hostile parties to agreement, essentially through such peaceful means as those foreseen in Chapter VI of the Charter of the United Nations." ASSEMBLEIA GERAL DAS NAÇÕES UNIDAS. Documentos da ONU reunindo um conjunto de acordos globais. Uma Agenda para a Pa₹. São Francisco, 17 jun. 1992. Disponível em: http://www.un-documents.net/a47-277.htm. Acesso em: 22 nov. 2017. prevenção do conflito, como para a criação da paz. 133 (Tradução nossa).

A grande diferença entre o peacekeeping e o peace enforcement, é que no peacekeeping se tem a imposição de "[...]forças neutrais e ligeiramente armadas na sequência da cessação das hostilidades, com a permissão do Estado em cujo território essas forças serão estacionadas [...]"134; enquanto no peace enforcement, a ausência de consentimento, em contexto de Estados em anarquia, conforme trazido por Annan, pode ser "nem certo, nem errado", mas "pura e simplesmente, irrelevante". ${ }^{135}$

Não obstante tal colocação, o relatório traz uma exceção ao requisito, afirmando que em casos em que não há tempo para o processo legal de autorização/determinação da intervenção, caracteriza-se uma exceção a tal pressuposto, desde que haja base para que se acredite que, mesmo que tivessem sido executadas, as medidas pacíficas não seriam suficientes para cessar a grave violação de direitos humanos. ${ }^{136}$

Wheeler, também nesse sentido, relaciona o requisito da última medida ao Princípio da Necessidade, de modo que afirma que, em casos em que a demora resultaria em dano irreparável, não é necessário que a intervenção seja a última alternativa. $\mathrm{O}$ autor defende a necessidade de que haja clara evidência de um massacre iminente, não sendo, no entanto, necessária a espera da ocorrência de tal massacre. ${ }^{137}$

133 "Peace-keeping is the deployment of a United Nations presence in the field, hitherto with the consent of all the parties concerned, normally involving United Nations military and/or police personnel and frequently civilians as well. Peace-keeping is a technique that expands the possibilities for both the prevention of conflict and the making of peace" ASSEMBLEIA GERAL DAS NAÇÕES UNIDAS. Documentos da ONU reunindo um conjunto de acordos globais. Uma Agenda para a Pa\%. São Francisco, 17 jun. 1992. Disponível em: http://www.un-documents.net/a47-277.htm. Acesso em: 22 nov. 2017.

134 PINTO, Maria do Céu. As Nações Unidas e a Manutenção da Paそ: e as actividades de peacekeeping doutras organizações internacionais. Coimbra: Almedina, 2007.p. 62.

135 ANNAN, Kofi A. "Challenges of the New Peacekeeping". In: OLARA A.; OTUNNU; DOYLE, Michael W. (ed.). Peacemaking and Peacekeeping for the New Century. Lanhammd: Rowman \& Littlefield, 1998. p. 172. Disponível em: http://www.ipris.org/ files/28/07PIn28_PintoS.pdf. Acesso em: 9 maio 2018.

136 International Commission on Intervention and State Sovereignty. The Responsibility to Protect. p. 36, dez. 2001. Disponível em: http://responsibilitytoprotect.org/ICISS\%20Report.pdf. Acesso em: 8 fev. 2018.

137 WHEELER, Nicholas J. Saving Strangers: Humanitarian Intervention in International Society. OUP Oxford, 7 de set de 2000. p. 34-5. Disponível em: <https://books.google.com. br/books?id=AYQLyuN4_twC\&printsec $=$ frontcover\&hl=pt- 
Ressalta-se que, mesmo que a intervenção militar ocorra de forma eficaz (fazendo cessar as violações), devem continuar a ocorrer ações que buscam a manutenção da paz alcançada. Por essa razão, o objetivo principal será sempre a consolidação da paz, ou seja, busca-se uma paz contínua e duradoura, ${ }^{138}$ estando abrangida a chamada responsabilidade de reconstruir. ${ }^{139}$

Assim, o Conselho de Segurança deve determinar, primeiramente, as medidas previstas no Capítulo VI da Carta, conhecidas como medidas de manutenção da paz; para, posteriormente, apenas caso se mostre necessário, fazer valer as medidas previstas no Capítulo VII, devendo a intervenção humanitária (art. 42) ser a última alternativa viável. Ou seja, deve fazer valer de todos os meios disponíveis, como esforços diplomáticos e sanções econômicas, antes de praticar a intervenção.

Ressalta-se que todas as medidas devem ser utilizadas de forma proporcional e visando o fim humanitário da ação, ou seja, as próprias medidas não podem

$\mathrm{BR} \&$ source $=\mathrm{gbs}$ ge_summary_r\&cad$=0 \#_{\mathrm{v}}=$ onepage $\& \mathrm{q} \& \mathrm{f}=\mathrm{fal}$ se>. Acesso em: 2 abr. 2018.

138 Nesse sentido, o preâmbulo da Carta das Nações Unidas consagra: «NÓS, OS POVOS DAS NAÇÕES UNIDAS, RESOLVIDOS a preservar as gerações vindouras do flagelo da guerra, que por duas vezes, no espaço da nossa vida, trouxe sofrimentos indizíveis à humanidade, e a reafirmar a fé nos direitos fundamentais do homem, na dignidade e no valor do ser humano, na igualdade de direito dos homens e das mulheres, assim como das nações grandes e pequenas, e a estabelecer condições sob as quais a justiça e o respeito às obrigações decorrentes de tratados e de outras fontes do direito internacional possam ser mantidos, e a promover o progresso social e melhores condições de vida dentro de uma liberdade ampla. E para tais fins praticar a tolerância e viver em paz, uns com os outros, como bons vizinhos, e unir as nossas forças para manter a paz e a segurança internacionais, e a garantir, pela aceitação de princípios e a instituição dos métodos, que a força armada não será usada a não ser no interesse comum, a empregar um mecanismo internacional para promover o progresso econômico e social de todos os povos. Resolvemos conjugar nossos esforços para a consecução desses objetivos." BRASIL. Decreto n ${ }^{\circ}$ 19.841, de 22 de outubro de 1945. Promulga a Carta das Nações Unidas, da qual faz parte integrante o anexo Estatuto da Corte Internacional de Justiça, assinada em São Francisco, a 26 de junho de 1945, por ocasião da Conferência de Organização Internacional das Nações Unidas. Disponível em: http://www.planalto.gov.br/ccivil_03/decreto/1930-1949/d19841.htm. Acesso em: 15 nov. 2017.

139 É o chamado peacebuilding (construção da paz), que busca “[...] evitar o reaparecimento de conflitos armados, mediante o apoio à construção e consolidação de sectores considerados cruciais para a estabilização de sociedades afectadas por conflitos", objetivando, em suma, identificar as causas dos conflitos, identificando meios para a resolução dos desacordos, a fim de, além de um mero cessar-fogo, construir e manter a paz. Em: PINTO, Maria do Céu. As Nações Unidas e a Manutenção da Pą: e as actividades de peacekeeping doutras organizações internacionais. Coimbra: Almedina, 2007. p. 9. causar mais danos do que benefícios. Nesse sentido, ao impor, por exemplo, sanções econômicas, o Conselho deve fazê-lo por um tempo determinado, que não se estenda o suficiente para causar danos prolongados à população. ${ }^{140}$

Contudo, conforme determinado pelo relatório, ou mesmo pelo texto literal do art. 42 da Carta, que autoriza a intervenção quando o "[...]Conselho de Segurança considerar que as medidas previstas no Artigo 41 seriam ou demonstraram que são inadequadas[...]", ${ }^{141}$ há situações que são tão graves e urgentes que justificam o uso da força imediato. ${ }^{142} \mathrm{~A}$ não determinação da intervenção humanitária em tais casos apenas prolongaria o contínuo sofrimento da população-alvo, o que pode, inclusive, levar ao seu extermínio. ${ }^{143}$

Em síntese, o requisito do último recurso quer dizer que devem ser tentadas todas as vias diplomáticas e não militares antes que o recurso da intervenção humanitária seja explorado, admitindo-se uma exceção: os casos em que há evidência suficiente da urgência da medida ou da inaptidão de outras medidas que não o uso da força.

\subsubsection{Os meios proporcionais}

O critério da proporcionalidade reflete a preocupação com os efeitos da intervenção, uma vez que esta não pode trazer males maiores do que os que visa cessar, devendo ser valorada para a legitimidade da intervenção os métodos utilizados para executá-la, de modo a alcançar o objetivo humanitário da intervenção, produzindo um bem maior do que o mal causado pela operação às partes afetadas. ${ }^{144}$

Deve existir uma proporcionalidade entre os direitos violados como consequência do uso da força para ga-

140 BETTATI, Mario. O Direito de Ingerência: mutação da ordem internacional. Lisboa: Instituto Piaget, 1996. p. 146.

141 Art. 42 da Carta.

142 International Commission on Intervention and State Sovereignty. The Responsibility to Protect. p. 34-5, dez. 2001. Disponível em: http://responsibilitytoprotect.org/ICISS\%20Report.pdf. Acesso em: 8 fev. 2018.

143 O DEBATE conceitual sobre intervenção humanitária. p. 77. Disponível em: https://www.maxwell.vrac.puc-rio. br/10564/10564_4.PDF. Acesso em: 3 maio 2018.

144 International Commission on Intervention and State Sovereignty. The Responsibility to Protect. p. 37, dez. 2001. Disponível em: http://responsibilitytoprotect.org/ICISS\%20Report.pdf. Acesso em: 8 fev. 2018. 
rantir os direitos humanos de determinada população e aqueles que de fato resultam assegurados pelo emprego de tal meio. ${ }^{145}$

Os objetivos da intervenção devem estar bem esclarecidos para que os meios utilizados sejam apenas o necessário para cumpri-los. A força pode ser utilizada desde que sem excesso e na medida do necessário, devendo sempre serem obedecidas as regras de Direito Internacional Humanitário, estrutura normativa que estipula os direitos e deveres em conflitos armados. ${ }^{146}$ Ainda, a intervenção deve cessar quando o objetivo desta for alcançado. Sua continuidade, após cessadas ou controladas as razões que lhe deram causa, tornam-na ilegítima. ${ }^{147}$

\subsubsection{Razoáveis chances de sucesso}

O relatório trouxe, ainda, requisito extremamente realista para validade da intervenção: o da necessidade a existência de fortes indícios de que a intervenção alcançará seu objetivo. ${ }^{148}$

A intervenção somente será possível se houver indícios de sucesso e se a garantia do seu sucesso não depender de ações mais prejudiciais do que as que já estão sendo causadas. Ou seja, a intervenção não pode ser mais prejudicial do que a não intervenção. ${ }^{149}$

A Comissão reconhece que esse requisito impossibilita, provavelmente, a intervenção contra grandes potências, no entanto, ressalta que há outros meios de pressionar essas, referindo-se às demais sanções previstas no Capítulo VII, que não a intervenção. ${ }^{150}$

145 SPIELER, Paula. A indeterminação do conceito de intervenção humanitária. Direito, Estado e Sociedade, n. 31 p. 9, jul./dez. 2007. Disponível em: http://www.jur.puc-rio.br/revistades/index.php/ revistades/article/view/265/240. Acesso em: 12 jan. 2018.

146 JUBILUT, Liliana Lyra. Não Intervenção e Legitimidade Internacional. São Paulo: Saraiva, 2010. p. 152.

147 International Commission on Intervention and State Sovereignty. The Responsibility to Protect. p. 37, dez. 2001. Disponível em: http:// responsibilitytoprotect.org/ICISS\%20Report.pdf. Acesso em: 8 fev. 2018.

148 International Commission on Intervention and State Sovereignty. The Responsibility to Protect. p. 37, dez. 2001. Disponível em: http://responsibilitytoprotect.org/ICISS\%20Report.pdf. Acesso em: 8 fev. 2018.

149 International Commission on Intervention and State Sovereignty. The Responsibility to Protect. p. 37, dez. 2001. Disponível em: http://responsibilitytoprotect.org/ICISS\%20Report.pdf. Acesso em: 8 fev. 2018.

150 International Commission on Intervention and State Sovereignty. The Responsibility to Protect. p. 37, dez. 2001. Disponível em:
Apesar de ser um critério realista, entendemos que não é um requisito que legitime ou deixe de legitimar a intervenção. Isso porque o fato de a intervenção ser mais prejudicial que as próprias violações está relacionado aos meios proporcionais, e não às razoáveis chances de sucesso. Ainda, no que diz respeito à impossibilidade de intervenção em grandes potências, se assim o fosse, por esse critério, não seria permissível a intervenção na Alemanha nazista de Hitler. ${ }^{151}$

Ressaltamos que o Conselho de Segurança pode, em acordo com o artigo 43 da Carta, solicitar dos membros forças armadas. Não se pode imaginar uma potência que será mais forte quando frente às forças armadas formadas por diversos Estados, a questão é a existência de cooperação entre os membros.

Não entendemos, portanto, que o fato de uma potência ser mais poderosa pode ser critério para impossibilidade da intervenção quando frente a reais atrocidades. Em casos de tamanhas violações, como aquelas ocasionadas pela Alemanha de Hitler, todos os demais Estados devem se unir para interromper tal situação, o que demonstraria a existência de uma verdadeira comunidade internacional.

\subsubsection{Autoridade competente}

A Comissão estabeleceu o Conselho de Segurança como autoridade competente para autorizar/determinar a intervenção, uma vez que este é o órgão dentro das Nações Unidas que tem responsabilidade primária na manutenção da paz e segurança internacionais, sendo a exceção ao Princípio da Não Intervenção e do Não Uso da Força. Nesse sentido é afirmado:

\footnotetext{
O mundo já tem uma organização diplomática e militar permanente com a capacidade (ainda que nem sempre a vontade) de lidar com todas as questões relativas à paz, segurança e problemas relacionados à proteção humana: nós a chamamos de Nações Unidas. ${ }^{152}$ (Tradução nossa).
}

http:// responsibilitytoprotect.org/ICISS\%20Report.pdf. Acesso em: 8 fev. 2018.

151 Nesse sentido: BIERRENBACH, Ana Maria. O Conceito de Responsabilidade de Proteger e o Direito Internacional Humanitário. Brasília: Fundação Alexandre Gusmão, 2011. p. 137.

152 "The world already has in place a standing military and diplomatic organization with the capacity (if not always the will) to deal with the whole spectrum of peace, security and human protection issues: we call it the United Nations." Em: International Commission on Intervention and State Sovereignty. The Responsibility to Protect. p. 37, dez. 2001. Disponível em: http://responsibilitytoprotect. 
As situações que possam caracterizar tamanha violação de direitos humanos que venha a ser determinada a intervenção, podem ser apresentadas ao Conselho por iniciativa dos Estados interessados, pelos próprios membros do Conselho ou pelo Secretário-Geral, conforme dispõe o art. 99.153

Apesar de o Conselho ter a responsabilidade primária na manutenção da paz, o relatório reconhece que essa responsabilidade não é exclusiva. $\mathrm{O}$ art. 10 da Carta ${ }^{154}$ dá à Assembleia Geral a responsabilidade secundária referente à manutenção da paz e segurança internacional (em casos de paralização do CSNU), ainda que apenas para fazer recomendações, uma vez que não tem o poder de tomar decisões vinculativas (como é o caso do CSNU). ${ }^{155}$ Além disso, poderá, diante da paralização do Conselho, autorizar o uso da força em sessão especial de emergência sob o procedimento Uniting for Peace. ${ }^{156}$

org/ICISS\%20Report.pdf. Acesso em: 8 fev. 2018.

153 "Artigo 99. S Secretário-Geral poderá chamar a atenção do Conselho de Segurança para qualquer assunto que em sua opinião possa ameaçar a manutenção da paz e da segurança internacionais." BRASIL. Decreto n ${ }^{\circ} 19.841$, de 22 de outubro de 1945. Promulga a Carta das Nações Unidas, da qual faz parte integrante o anexo Estatuto da Corte Internacional de Justiça, assinada em São Francisco, a 26 de junho de 1945, por ocasião da Conferência de Organização Internacional das Nações Unidas. Disponível em: http://www.planalto. gov.br/ccivil_03/decreto/1930-1949/d19841.htm. Acesso em: 27 fev. 2018.

154 “Artigo 10. A Assembleia Geral poderá discutir quaisquer questões ou assuntos que estiverem dentro das finalidades da presente Carta ou que se relacionarem com as atribuições e funções de qualquer dos órgãos nela previstos e, com exceção do estipulado no Artigo 12, poderá fazer recomendações aos Membros das Nações Unidas ou ao Conselho de Segurança ou a este e àqueles, conjuntamente, com referência a qualquer daquelas questões ou assuntos." BRASIL. Decreto no 19.841, de 22 de outubro de 1945. Promulga a Carta das Nações Unidas, da qual faz parte integrante o anexo Estatuto da Corte Internacional de Justiça, assinada em São Francisco, a 26 de junho de 1945, por ocasião da Conferência de Organização Internacional das Nações Unidas. Disponível em: http:/ /www.planalto.gov.br/ccivil_03/decreto/1930-1949/d19841.htm. Acesso em: 27 fev. 2018.

155 International Commission on Intervention and State Sovereignty. The Responsibility to Protect. p. 37, dez. 2001. Disponível em: http://responsibilitytoprotect.org/ICISS\%20Report.pdf. Acesso em: 8 fev. 2018.

156 A resolução 377 da Assembleia Geral, denominada Uniting for Peace trouxe como principal inovação que, em caso de omissão do Conselho por falta de unanimidade entre seus membros, a Assembleia-Geral consideraria os assuntos, podendo fazer recomendações aos Estados-membros para medidas coletivas, inclusive sobre assuntos referentes ao uso da força. ASSEMBLEIA GERAL DAS NAÇÕES UNIDAS. Resolução 377. Disponível em: http:// www.un.org/en/sc/repertoire/otherdocs/GAres377A(v).pdf. Acesso em: 17 abr. 2018.
Outra solução trazida pela Comissão no caso de omissão do CSNU, decorrente da falta de unanimidade entre seus membros, é a possibilidade de ação por organizações regionais ou sub-regionais dentro da área de jurisdição, em conformidade com o Capítulo VIII da Carta, desde que sujeitas à autorização subsequente do Conselho de Segurança. No entanto, alerta:

O Conselho de Segurança deverá levar em consideração em todas as deliberações que, se falhar em exercer sua responsabilidade de proteger em situações que chocam a consciência que clamam atenção, Estados interessados podem não desconsiderar outros meios de alcançar a gravidade e urgência da situação - e a reputação e credibilidade das Nações Unidas pode sofrer por isso. ${ }^{157}$ (Tradução nossa).

Assim, a Comissão acabou por se pronunciar a respeito de uma situação muito controvertida na doutrina, qual seja, a possibilidade da intervenção unilateral, em casos de omissão do CSNU diante de situações que caracterizam uma justa causa, ou seja, conforme denominadas no relatório: situações que chocam a consciência da humanidade.

Esse também o posicionamento de Michael Walzer, que afirma que tanto intervenções unilaterais quanto coletivas podem estar revestidas de vontades impurasque não tem por único objetivo a cessão das atrocidades - e que confiar num único agente global para a proteção de direitos fundamentais, acarreta em desvantagens óbvias. ${ }^{158}$

Dessa forma, o autor expõe que, apesar de a intervenção unilateral ser proibida pelo paradigma legalista, estas são legítimas quando caracterizados crimes contra a humanidade (conforme Código de Nuremberg). ${ }^{159}$ Assim conclui:

Qualquer Estado capaz de impedir a carnificina tem

157 "The Security Council should take into account in all its deliberations that, if it fails to discharge its responsibility to protect in conscience-shocking situations crying out for action, concerned states may not rule out other means to meet the gravity and urgency of that situation - and that the stature and credibility of the United Nations may suffer thereby." International Commission on Intervention and State Sovereignty. The Responsibility to Protect. p.XIII, dez. 2001. Disponível em: http://responsibilitytoprotect.org/ICISS $\% 20$ Report.pdf. Acesso em: 8 fev. 2018.

158 WALZER, Michael. Guerras Justas e Injustas: uma argumentação moral com exemplos históricos. São Paulo: Martins Fontes, 2003. p. XVI-XVIII.

159 WALZER, Michael. Guerras Justas e Injustas: uma argumentação moral com exemplos históricos. São Paulo: Martins Fontes, 2003. p. $181-2$. 
o direito, no mínimo, de tentar reagir. O paradigma legalista de fato exclui esforços dessa natureza, mas isso apenas sugere que o paradigma, sem revisões, não tem como dar conta das realidades morais da intervenção militar. ${ }^{160}$

A Comissão, no que se refere à atuação de organizações regionais e sub-regionais com amparo no Capítulo VIII, aceita que a autorização do Conselho seja subsequente à intervenção. ${ }^{161}$

Percebe-se que as intervenções unilaterais não são ideais, uma vez que dão azo à utilização da força fora das situações determinadas na Carta. Não obstante, devemos reconhecer que muitas vezes o Conselho torna-se omisso diante do poder de veto. A ação unilateral acaba sendo o resultado da ineficiência do sistema de segurança coletiva da ONU. Conclui-se, portanto, segundo o Relatório da ICISS, que o Conselho de Segurança tem competência primária para autorizar a intervenção, mas não exclusiva. Em caso de ações unilaterais, estas poderão ser legalizadas com a posterior autorização do Conselho. ${ }^{162}$

O cumprimento dos critérios acima apresentados pela ICISS, conforme ressaltado pelo próprio relatório, não eliminam as possibilidades de eventuais abusos, ainda sendo necessária a evolução, principalmente no sentido de controle de legalidade das ações do Conselho. Além disso, ressalta-se que, apesar de não serem critérios objetivos impostos ao órgão para determinação da intervenção, é um grande avanço nos debates da comunidade internacional quanto a medida.

Assim, a partir de maiores debates entre os Estados-membros, que são os possibilitadores da intervenção (uma vez que a ONU não possui forças armadas próprias), cria-se maior consciência a respeito do uso da força e da necessidade do uso deste apenas em situações extremas, devendo os próprios Estados agirem como um controle de legalidade do Conselho de Segurança, a fim de que as medidas tomadas por este estejam revestidas de legitimidade.

160 WALZER, Michael. Guerras Justas e Injustas: uma argumentação moral com exemplos históricos. São Paulo: Martins Fontes, 2003. p. 184.

161 International Commission on Intervention and State Sovereignty. The Responsibility to Protect. p. 37, dez. 2001. Disponível em: http://responsibilitytoprotect.org/ICISS\%20Report.pdf. Acesso em: 8 fev. 2018.

162 Nesse sentido: WALZER, Michael. Guerras Justas e Injustas: uma argumentação moral com exemplos históricos. São Paulo: Martins Fontes, 2003.
Além das importantes inovações trazidas pela Comissão, o Brasil apresentou em 2012 um novo conceito para o avanço da responsabilidade de proteger: a responsabilidade ao proteger (ou responsability while protecting, RwP, sigla em inglês).

\subsection{A Responsabilidade ao Proteger}

Em setembro de 2011, a então presidente, Dilma Roussef, apresentou um discurso à Assembleia Geral da ONU no qual apresentou um novo conceito relacionado ao uso da força pelas Nações Unidas: a responsabilidade ao proteger. Além da responsabilidade de proteger, o conceito inclui a necessidade de conscientização quanto às consequências e meios da intervenção, ressaltando a necessidade de proteção aos civis frente as possíveis consequências negativas da medida. ${ }^{163}$

Após a apresentação do discurso, a diplomacia brasileira, representada pela embaixadora do Brasil na ONU, Maria Luiza Ribeira Viotti, apresentou uma nota conceitual com os elementos para o desenvolvimento e promoção do conceito responsabilidade ao proteger. Neste, frisa que, mesmo quando revestida de justiça, legalidade e legitimidade, a intervenção tem altos custos materiais e humanos, sendo imperativo a procura e exaustão de todos os meios pacíficos para resolução dos litígios antes do uso da força. Assim, ressalta a necessidade de evolução e aplicação de ambos os conceitos, devendo seguir princípios, parâmetros e procedimentos fundamentais, que elenca:
(a) [...] prevenção é sempre a melhor política [...];
(b) a comunidade internacional deve ser rigorosa nos seus esforços de exaurir todos os meios pacíficos disponíveis na proteção de civis ameaçados de violência, de acordo com os princípios e propósitos da Carta das Nações Unidas [...];
(c) o uso da força incluindo no exercício da responsabilidade de proteger, deve ser sempre autorizado pelo Conselho de Segurança, de acordo com o Capítulo VII da Carta, ou, em circunstâncias excepcionais, pela Assembleia Geral, de acordo com a Resolução 377;

163 BRASIL. Ministério das Relações Exteriores. Pronunciamento do Ministro das Relacõos Exteriores, Antonio de Aguiar Patriota, em debate sobre responsabilidade ao proteger na ONU. Nova York, 21 de fevereiro de 2012. 22 fev. 2012. Disponível em: http:/ /www.itamaraty.gov.br/ pt-BR/notas-a-imprensa/8653-pronunciamento-do-ministro-dasrelacoes-exteriores-antonio-de-aguiar-patriota-em-debate-sobreresponsabilidade-ao-proteger-na-onu-nova-york-21-de-fevereirode-2012. Acesso em: 3 maio 2018. 
(d) a autorização do uso da força deve ser limitada pelos seus elementos legais, operacionais e temporais e o escopo da ação militar deve [...] seguir estritamente em conformidade com as leis internacionais, em particular a lei internacional humanitária e a lei internacional de conflito armado;

(e) o uso da força deve produzir o mínimo de violência e instabilidade quanto possível. Sob quaisquer circunstâncias pode ele gerar mais mal do que foi autorizado a prevenir;

(f) caso o uso da força seja contemplado, a ação deve ser sensata, proporcional e limitada aos objetivos estabelecidos pelo Conselho de Segurança;

(g) essas diretrizes devem ser observadas durante todo período da autorização, desde a adoção da resolução até a suspensão da autorização por uma nova resolução;

(h) melhores procedimentos do Conselho de Segurança são necessários para monitorar e avaliar a maneira em que as resoluções são interpretadas e implementadas para garantir a responsabilidade ao proteger;

(i) o Conselho de Segurança deve garantir a responsabilidade daqueles a quem a autoridade é concedida para recorrer à força. ${ }^{164}$ (Tradução nossa).

$\mathrm{Na}$ verdade, a responsabilidade ao proteger reforça muitos dos requisitos que já haviam sido apresentados

164 “(a) [...] prevention is always the best policy [...]; (b) The international community must be rigorous in its efforts to exhaust all peaceful means available in the protection of civilians under threat of violence, in line with the principles and purposes of the Charter $[\ldots]$; (c) The use of force, including in the exercise of the responsibility to protect, must always be authorized by the Security Council, in accordance with Chapter VII of the Charter, or, in exceptional circumstances, by the General Assembly, in line with its resolution 377; (d) The authorization for the use of force must be limited in its legal, operational and temporal elements and the scope of military action must abide by the letter and the spirit of the mandate conferred by the Security Council or the General Assembly, and be carried out in strict conformity with international law, in particular international humanitarian law and the international law of armed conflict; (e) The use of force must produce as little violence and instability as possible and under no circumstance can it generate more harm than it was authorized to prevent; (f) In the event that the use of force is contemplated, action must be judicious, proportionate and limited to the objectives established by the Security Council; (g) These guidelines must be observed throughout the entire length of the authorization, from the adoption of the resolution to the suspension of the authorization by a new resolution; (h) Enhanced Security Council procedures are needed to monitor and assess the manner in which resolutions are interpreted and implemented to ensure responsibility while protecting; (i) The Security Council must ensure the accountability of those to whom authority is granted to resort to force." ASSEMBLEIA GERAL DAS NAÇÕES UNIDAS. Conselho de Segurança. A/66/551-S/2011/701. 11 nov. 2011. Disponível em: http://www.globalr2p.org/media/files/concept-paper-_rwp.pdf. Acesso em: 25 abr. 2018. no relatório da ICISS, ressaltamos, nesse sentido, que a Comissão apresentou seis princípios operacionais a serem seguidos nas intervenções, além da responsabilidade de reconstruir. No entanto, traz grande divergência: a impossibilidade do uso da força caso as demais medidas não tenham sido adotadas e falhado, sendo, portanto, um conceito mais limitador da intervenção.

O novo conceito apresentado pelo Brasil traz importante observação que não foi objeto de análise anteriormente: a necessidade de controle pelo Conselho de Segurança da intervenção, a fim de garantir a ausência de abusos no decorrer da intervenção, bem como a fim de poder averiguar o momento em que a medida já não se faz mais necessária.

Assim, percebe-se que a análise da legitimidade não se esgota no momento de autorização da intervenção pelo CSNU, podendo ocorrer apenas quando finda a ação, uma vez que uma intervenção inicialmente legítima, pode se tornar ilegítima quando emprega o uso da força além do necessário, ou quando acaba causando mais males do que caso a intervenção não tivesse ocorrido. ${ }^{165}$

Apesar de ainda não haver consenso na comunidade internacional sobre o tema, é irrefutável que, quanto mais debates, maiores serão as chances de evolução da intervenção, a fim de alcançar conceitos objetivos que legitimam a ação, limitando a discricionariedade do Conselho de Segurança nas decisões e alcançando maior cooperação internacional para o alcance e manutenção da paz.

\section{Considerações Finais}

O presente artigo se concentrou na análise da legalidade e legitimidade da intervenção militar humanitária, objetivando analisar quando será possível afirmar que uma intervenção foi legal e legítima, colocando a possibilidade da intervenção frente aos princípios norteadores do Direito Internacional e elencando, a partir da análise do atual principal documento internacional sobre o assunto - o relatório da ICISS intitulado $A$ Responsabilidade de Proteger - , quais são os critérios para

165 Nesse sentido: International Commission on Intervention and State Sovereignty. The Responsibility to Protect. p. 37, dez. 2001. Disponível em: http://responsibilitytoprotect.org/ICISS\%20Report.pdf. Acesso em: 8 fev. 2018. 
a legitimidade de uma intervenção.

A legalidade da intervenção humanitária traz grandes debates para os pesquisadores da matéria, uma vez que acaba por ser uma exceção a três dos princípios norteadores do Direito Internacional: o princípio da soberania, do não uso da força e da não intervenção.

Não obstante a posição defendida por alguns doutrinadores, a posição majoritariamente aceita, conforme exposto, é a do intervencionismo limitado, que aceita a ocorrência da intervenção em situações de extrema violação dos direitos humanos, que ferem a consciência moral da humanidade, ou seja, situações de violação das normas jus cogens em alta escala.

Constatamos que tais violações constituem uma ameaça à paz e à segurança internacionais, havendo um dever moral e direito legal, sob o amparo do art. 42 da Carta das Nações Unidas, da comunidade internacional de intervir. Tal dever recai sobre os ombros do Conselho de Segurança das Nações Unidas, uma vez que é ele o órgão guardião da segurança coletiva, tendo monopólio para autorizar/determinar as medidas coercitivas, representando os Estados-membros. Em segundo plano, nos casos de paralisação do CSNU devido à ameaça do uso do veto, a Assembleia Geral da ONU pode fazer recomendações aos assuntos referentes à proteção da paz e segurança internacionais, não tendo, no entanto, a força vinculante de uma decisão do Conselho. O relatório também admitiu a possibilidade da ação por organizações regionais ou sub-regionais dentro de sua área de jurisdição, em conformidade com o Capítulo VIII da Carta, apenas nos casos de total omissão do CSNU, estando a ação, no entanto, sujeita a posterior autorização do Conselho, o que caracterizaria uma legalidade $a$ posteriori.

Foram, portanto, estas as formas que uma intervenção poderá ser autorizada/determinada e ser considerada legal: quando autorizadas ou determinadas pelo Conselho de Segurança. A autorização poderá ser posterior à intervenção face à inicial omissão do CSNU, e quando recomendada pela Assembleia Geral, frente à total omissão do CSNU.

A utilização da força para a proteção de civis — que caracteriza uma intervenção humanitária — não pode ser tratada com banalidade, deixando a bel prazer dos Estados membros permanentes do Conselho de Segurança - uma vez que suas decisões não estão, efetivamente, sujeitas a qualquer controle de legalidade/legiti- midade - a discricionariedade acerca de quais situações de desastre humanitário merecem a ajuda internacional, e quais não merecem. Devem existir critérios que norteiem as decisões do órgão, a fim de haver um padrão nas decisões.

Diante dessa problemática, a Comissão Internacional sobre Intervenção e Soberania dos Estados desenvolveu o relatório $A$ Responsabilidade de Proteger, trazendo critérios que, embora aparentemente objetivos, na realidade ainda estão sujeitos a diferentes interpretações, de modo que não tirou das mãos do CSNU a discricionariedade do órgão, apenas tendo apresentado elementos a fim de nortear suas decisões. O relatório foi aprovado pela ONU em 2005, mostrando sua relevância para a comunidade internacional.

O documento trouxe seis critérios para que o Conselho de Segurança possa autorizar uma intervenção humanitária, bem como seis princípios operacionais a serem seguidos, ou seja, não limitou a análise da legitimidade da intervenção ao momento de autorização/ determinação desta por parte do CSNU, expandido a análise a três momentos que se referem à motivação da autorização, aos meios utilizados e ao prolongamento da intervenção.

Além do documento acima mencionado, analisamos a proposta apresentada pelo governo brasileiro a respeito da responsabilidade ao proteger, que limitou ainda mais a possibilidade da intervenção e deu ênfase às medidas de prevenção que devem ser tomadas pela comunidade internacional, a fim de impedir que um conflito internacional, ainda que interestatal, torne-se causador de graves violações de direitos humanos. Apesar de a discussão sobre o assunto ser de suma importância, uma vez que, conforme já dito, a inexistência de critérios objetivos não impedem a determinação de intervenções e acabam por gerar uma falta de padrão nas decisões, as contribuições feitas pelo governo brasileiro não foram extensivas no sentido de trazer critérios a fim de nortear as decisões do Conselho, tendo apenas reafirmado argumentos já trazidos pelo relatório da ICISS.

Assim, percebe-se que os documentos referidos são de suma importância por trazerem novamente ao centro das discussões as intervenções humanitárias, possibilitando a troca de novas ideias com o intuito de aprimorar o conceito e o que constitui uma intervenção legítima, a fim de que os critérios, nos quais se baseiam a decisão que determina a intervenção, não sejam discri- 
minatórios e não tenham como foco objetivos políticos dos Estados envolvidos, mas tenham, como última e efetiva finalidade, a intenção de salvaguardar os direitos fundamentais do ser humano.

Os direitos humanos mais fundamentais, tidos como normas jus cogens, devem estar acima de qualquer noção de impermeabilidade estatal, uma vez que são obrigações do Estado o respeito e a proteção dos direitos fundamentais dos indivíduos que estão dentro de suas fronteiras. A grave violação de tais direitos deve provocar a ação do Conselho de Segurança, uma vez que é órgão reconhecido pela maioria dos Países como protetor da paz e segurança internacional, sendo sua a responsabilidade secundária (a responsabilidade primária é do próprio Estado) de defesa de tais conceitos, o que abrange, conforme demonstrado pelas resoluções precedentes do órgão, a defesa dos direitos humanos básicos dos indivíduos, quando violados em alta escala.

Em segundo plano, reconhecemos a possibilidade de o CSNU se ver incapacitado de agir pela ameaça do veto - por tal razão, defendemos a necessidade da reforma do órgão, a fim de garantir maior representatividade dos membros; ou, ainda, a criação de um novo órgão competente para decidir acerca de questões que envolvam a segurança humana e a proteção dos direitos humanos, composto por juízes independentes, sendo estas duas possíveis soluções para o problema do veto e da imparcialidade - momento no qual é reconhecida a possibilidade de atuação de um Estado independente, atuando não por haver uma existência de um dever legal, mas sim um dever moral de agir, que pode, quando estão presentes razões humanitárias (além dos outros requisitos já mencionados), dispor de legitimidade.

Dessa forma percebemos que ainda não há um consenso internacionalmente quanto ao momento em que uma intervenção será legal, estando a maior divergência ligada à possibilidade das intervenções unilaterais. Atualmente, majoritariamente, afirma-se que a legalidade advém de uma autorização/determinação feita pelo CSNU. Quanto à legitimidade, ainda não se pode afirmar que há critérios objetivos estabelecidos, no entanto, os preceitos elencados pela ICISS no relatório $A$ Responsabilidade de Proteger devem ser norteadores das decisões do Conselho, que ainda possui grande discricionariedade quanto ao uso da força por questões humanitárias ou que ameacem a paz. Diante disso, mostra-se de extrema importância que os Estados se unam em prol da estabi- lidade das decisões, buscando evoluir nas questões que envolvem o uso de força, de modo a garantir um efetivo sistema democrático, que busque garantir a segurança humana de maneira imparcial e transparente, tendo sempre em mente o melhor interesse da humanidade.

\section{ReferênCias}

ACCIOLY, Hildebrando. Manual de Direito Internacional Público. São Paulo: Saraiva, 2015. Livro Eletrônico.

ACCIOLY, Hildebrando; SILVA, Geraldo Eulálio do Nascimento e; CASELLA, Paulo Borba. Manual de Direito Internacional Público. 22. ed. São Paulo: Saraiva, 2016.

Accordance with international law of the unilateral declaration of independence in respect of Kosovo. International Court of Justice, 22 jul. 2010. Disponível em: http://www.icj-cij.org/files/case-related/141/16010. pdf. Acesso em: 11 dez. 2017.

AMARAL JÚNIOR, Alberto do. O Direito de Assistência Humanitária. Rio de Janeiro: Renovar, 2003.

AMORIM, João Alberto Alves. A ONU e o Meio Ambiente: Direitos humanos, mudanças climáticas e segurança internacional no século XXI. São Paulo: Atlas, 2015.

ANNAN, Kofi A. "Challenges of the New Peacekeeping”. In: OLARA A.; OTUNNU; DOYLE, Michael W. (ed.). Peacemaking and Peacekeeping for the New Century. Lanhammd: Rowman \& Littlefield, 1998. p. 172. Disponível em: http://www.ipris.org/files/28/07PIn28_ PintoS.pdf. Acesso em: 9 maio 2018.

ANNAN, Kofi A. Intervenções: uma vida de guerra e paz. São Paulo: Companhia das Letras, 2013.

ANNAN, Kofi A. The Question of Intervention. New York: United Nations Department of Public Information, 1999.

ANNAN, Kofi A. Two concepts of sovereignty. The Economist. 18 set. 1999. Disponível em: http://nbksdbd.tamilnet.com/img/publish/2008/01/TwoconceptsofsovereigntyAnnan.pdf. Acesso em: 20 dez. 2017.

ARNAUD, André-Jean. O Direito entre Modernidade e Globalização: lições de filosofia do direito e do estado. Rio de Janeiro: Renovar, 1999.

ARON, Raymond. Paz e Guerra entre as Nações. Brasília: Editora Universidade de Brasília; São Paulo: Imprensa 
Oficial do Estado de São Paulo, 2002.

ASSEMBLEIA GERAL DAS NAÇÕES UNIDAS. Conselho de Segurança. A/55/305-S/2000/809. 21 ago. 2000. Disponível em: http://www.un.org/en/ga/ search/view_doc.asp?symbol=A/55/305. Acesso em: 27 abr. 2018.

ASSEMBLEIA GERAL DAS NAÇÕES UNIDAS. Conselho de Segurança. A/66/551-S/2011/701. 11 nov. 2011. Disponível em: http://www.globalr2p.org/ media/files/concept-paper-_rwp.pdf. Acesso em: 25 abr. 2018.

ASSEMBLEIA GERAL DAS NAÇÕES UNIDAS. Conselho de Segurança. S/RES/1160 (1998). 31 mar. 1998. Disponível em: http://www.un.org/en/ga/search/view_doc.asp?symbol=S/RES/1160(1998). Acesso em: 3 maio 2018.

ASSEMBLEIA GERAL DAS NAÇÕES UNIDAS. Conselho de Segurança. S/RES/1199 (1998). Disponível em: http://www.un.org/en/ga/search/view_ doc.asp?symbol=S/RES/1199(1998). Acesso em 3 maio 2018.

ASSEMBLEIA GERAL DAS NAÇÕES UNIDAS. Declaração Universal dos Direitos Humanos. 10 dez. 1948. Disponível em: http://www.un.org/en/universal-declaration-human-rights/. Acesso em: 20 mar. 2018.

ASSEMBLEIA GERAL DAS NAÇÕES UNIDAS. Documentos da ONU reunindo um conjunto de acordos globais. Uma Agenda para a Pa: São Francisco, 17 jun. 1992. Disponível em: http://www.un-documents. net/a47-277.htm. Acesso em: 22 nov. 2017.

ASSEMBLEIA GERAL DAS NAÇÕES UNIDAS. Relatório do Terceiro Comitê A/RES/53/144. 8 mar. 1999. Disponível em: http:/ /www.ohchr.org/Documents/Issues/Defenders/Declaration/declaration.pdf. Acesso em: 20 mar. 2018.

ASSEMBLEIA GERAL DAS NAÇÕES UNIDAS. Relatório do Terceiro Comitê A/70/163. 10 fev. 2016. Disponível em: http://www.un.org/en/ga/search/view_ doc.asp?symbol=A/RES/70/163.

ASSEMBLEIA GERAL DAS NAÇÕES UNIDAS. Resolução 377. Disponível em: http://www.un.org/en/sc/ repertoire/otherdocs/GAres377A(v).pdf. Acesso em: 17 abr. 2018.

ASSEMBLEIA GERAL DAS NAÇÕES UNIDAS. Resolução $n$ 36/103. Disponível em: http://www.un.org/
es/comun/docs/?symbol=A/RES/36/103. Acesso em: 2 mar. 2018.

ASSEMBLEIA GERAL DAS NAÇÕES UNIDAS. Resolution adopted by the General Assembly on 16 September 2005. A/RES/60/1. p. 32, 24 out. 2005. Disponível em: https://undocs.org/A/RES/60/1. Acesso em: 20 mar. 2018.

ASSEMBLEIA GERAL DAS NAÇÕES UNIDAS. Resultado da Cupula Mundial de 2005 A/RES/60/1. p. 30, 32, 24 out. 2005. Disponível em: https://undocs. org/A/RES/60/1. Acesso em: 20 mar. 2018.

ASSEMBLEIA GERAL DAS NAÇÕES UNIDAS. Security Council. Resolution 794 (1992). S/RES/794 (1992). Disponível em: http://www.un.org/en/ga/search/view_doc.asp?symbol=S/RES/794(1992). Acesso em: 5 mar. 2018.

ASSEMBLEIA GERAL DAS NAÇÕES UNIDAS. Security Council. Resolution 824 (1993). S/RES/824 (1993). Disponível em: http://www.un.org/en/ga/search/view_doc.asp?symbol=S/RES/824(1993). Acesso em: 5 mar. 2018.

BEDJAOUI, Mohammed. President of the International Court of Justice The Hague, p. 24, 9 ago. 1994. Disponível em: http://www.icj-cij.org/files/annualreports/1993-1994-en.pdf. Acesso em: 20 abr. 2018.

BETTATI, Mario. O Direito de Ingerência: mutação da ordem internacional. Lisboa: Instituto Piaget, 1996.

BIERRENBACH, Ana Maria. O Conceito de Responsabilidade de Proteger e o Direito Internacional Humanitário. Brasília: Fundação Alexandre Gusmão, 2011.

BOBBIO, Norberto. Dicionário de Política. In: MOREIRA, Felipe Kern. Direito e Legitimidade na Sociedade Internacional. Boa Vista: Editora da Universidade Federal de Roraima, 2012. p. 60.

BORGES, Leonardo Estrela. O Direito Internacional Humanitário. Belo Horizonte: Del Rey, 2006.

BRASIL. Decreto no 19.841, de 22 de outubro de 1945. Promulga a Carta das Nações Unidas, da qual faz parte integrante o anexo Estatuto da Corte Internacional de Justiça, assinada em São Francisco, a 26 de junho de 1945, por ocasião da Conferência de Organização Internacional das Nações Unidas. Disponível em: http:/ / www.planalto.gov.br/ccivil_03/decreto/1930-1949/ d19841.htm. Acesso em: 12 abr. 2018. 
BRASIL. Decreto n² 25.660, de 13 de outubro de 1948. Manda executar o Tratado Interamericano de Assistência Recíproca, firmado no Rio de Janeiro, a 2 de setembro de 1947, por ocasião da Conferência Interamericana para a manutenção da paz e da segurança do Continente. Disponível em: http://www2.camara.leg.br/legin/ fed/decret/1940-1949/decreto-25660-13-outubro1948-322840-publicacaooriginal-1-pe.html. Acesso em: 04 mar. 2018.

BRASIL. Ministério das Relações Exteriores. Pronunciamento do Ministro das Relações Exteriores, Antonio de Aguiar Patriota, em debate sobre responsabilidade ao proteger na ONU - Nova York, 21 de fevereiro de 2012. 22 fev. 2012. Disponível em: http://www.itamaraty.gov.br/pt-BR/ notas-a-imprensa/8653-pronunciamento-do-ministrodas-relacoes-exteriores-antonio-de-aguiar-patriota-emdebate-sobre-responsabilidade-ao-proteger-na-onunova-york-21-de-fevereiro-de-2012. Acesso em: 3 maio 2018.

BROWNLIE, Ian. Memorandum to the Comittee on Foreign Affairs. Disponível em: https://publications.parliament. $\mathrm{uk} / \mathrm{pa} / \mathrm{cm} 199900 / \mathrm{cmselect} / \mathrm{cmfaff} / 28 / 28$ ap03.htm. Acesso em: 09 de maio de 2018.

BULL, Hedley. A Sociedade Anárquica [1]. Brasília: UnB, 2002. Disponível em: http://funag.gov.br/loja/ download/158-Sociedade_Anarquica_A.pdf. Acesso em: 5 mar. 2018.

CASE Concerning Military and Paramilitary Activities in and Against. International Court of Justice, Nicaragua, 27 jun. 1986. Disponível em: http://www.icj-cij. org/files/case-related/70/070-19860627-JUD-01-00EN.pdf. Acesso em: 16 abr. 2018.

CASSESE, Antonio. Existe um conflito insuperável entre soberania dos Estados e justiça penal internacional? In: CASSESE, Antonio; DELMAS-MARTY, Mireille (org.). Crimes Internacionais e Jurisdições Internacionais. São Paulo: Manole, 2004. p. 13.

CAVALIERI FILHO, Sérgio. Programa de Responsabilidade Civil. 12. ed. Rio de Janeiro: Grupo GEN, 2015.

CHESTERMAN, Simon. Just War or Just Peace? Oxford: Oxford University Press, 2002. Disponível em: https:/ / books.google.com.br/books?id=DNUPcfTOIJEC\&pg $=\mathrm{PA} 45 \& \mathrm{hl}=\mathrm{pt}-\mathrm{BR} \&$ source $=\mathrm{gbs} \_$toc_r\&cad $=4 \# \mathrm{v}=$ on epage\&q\&f=false. Acesso em: 22 jan. 2018.

CICV. Comitê Internacional da Cruz Vermelha. Métodos e os meios de Guerra. Panorama, 29 out. 2010. Disponível em: https://www.icrc.org/por/war-and-law/conducthostilities / methods-means-warfare/overview-methods-and-means-of-warfare.htm. Acesso em: 2 maio 2018.

CINELLI, Carlos Frederico. Direito Internacional Humanitário: ética e legitimidade no uso da força em conflitos armados. Curitiba: Juruá, 2016.

COADY, C. A. J. The Ethics of Armed Humanitarian Intervention. 2002. p. 10-1. Disponível em: http://citeseerx. ist.psu.edu/viewdoc/download?doi=10.1.1.197.8523\& rep $=$ rep1\&type=pdf. Acesso em: 11 jan. 2018.

D'AMATO, Anthony A. International Law Studies. 26 fev. 1997. p. 378. Disponível em: https:// books.google.com.br/books? id =uNuYKduz_ $\mathrm{kAC} \&$ printsec $=$ frontcover\&hl $=\mathrm{pt}-\mathrm{BR} \&$ source $=\mathrm{gbs}$ ge_summary_r\&cad $=0 \#_{\mathrm{v}}=$ onepage $\& \mathrm{q}=$ intervention $\& \mathrm{f}=$ false. Acesso em: 3 mar. 2018.

DAUDT, Gabriel Pithan. Reservas aos Tratados Internacionais de Direitos Humanos: o conflito entre a eficácia e a promoção dos direitos humanos. Porto Alegre: Sergio Antonio Fabris, 2006.

DIREITO, Carlos Alberto Menezes; TRINDADE, Antônio Augusto Cançado; PEREIRA, Antônio Celso Alves (coord.). Novas Perspectivas do Direito Internacional Contemporâneo: estudos em homenagem ao Professor Celso D. de Albuquerque Mello. Rio de Janeiro: Renovar, 2008. p. 3-24.

DISSENTING opinion of Judge Weeramantry. Montreal Convention (DISS. OP. WEERAMANTRY). 1971. p. 55, 57. Disponível em: http:/ /www.icj-cij.org/ files / case-related/88/088-19920414-ORD-01-07-EN. pdf. Acesso em: 20 abr. 2018.

EDITORIAL Comments: Nato's Kosovo Intervention. The American Journal of International Law, v. 92, p. 847. Disponível em: https://www.cambridge. org/core/services / aop-cambridge-core/content/ view/BD11A1D4AF26B1E78EF1A296C1C29B06/ S0002930000027433a.pdf/kosovo_world_order_and_ the_future_of_international_law.pdf. Acesso em: 10 fev. 2018.

FALK, Richard A. Kosovo, world ordr, and the future of international law. American Journal of International Law, v. 92, n. 4, p. 847-57, 1999. Disponível em: https://www. cambridge.org/core/journals/american-journal-of- 
international-law/article/kosovo-world-order-and-thefuture-of-international-law/BD11A1D4AF26B1E78EF1A296C1C29B06. Acesso em: 13 fev. 2018.

FALK, Richard A. Legality and Legitimacy: the quest for principled flexibility and restraint. Review of International Studies, 21 mar. 2006. Disponível em: https:// www.cambridge.org/core/services/aop-cambridgecore/content/view/684FF725D304FB11384E90795 7BF9995/S0260210505006777a.pdf/legality_and_legitimacy_the_quest_for_principled_flexibility_and_restraint.pdf. Acesso em: 13 fev. 2018.

FALK, Richard A. The Complexities of Humanitarian Intervention: A New World Order Challenge. Michigan Journal of International Law, v. 17, n. 2, 1996. Disponível em: https:/ / repository.law.umich.edu/cgi/viewcontent. cgi? article $=1498 \&$ context $=$ mjil. Acesso em: 10 jan . 2018.

FIXDAL, Mona; SMITH, Dan. Humanitarian Intervention and Just War. Mershon International Studies Review, v. 42, n. 2, p. 4, nov. 1998. Disponível em: https:// blackboard.angelo.edu/bbcswebdav/institution/LFA/ CSS /Course\%20Material/SEC6302/Readings/Lesson_4/Fixdal-Smith.pdf. Acesso em: 5 mar. 2018.

FONSECA JÚNIOR, Gelson. A Legitimidade e Outras Questões Internacionais. Rio de Janeiro: Paz e Terra, 1998.

FRANÇA, Paulo Roberto Caminha de Castilhos. A Guerra do Kosovo, a OTAN e o Conceito de "Intervenção Humanitária”. Porto Alegre: Editora da UFGRS, 2004.

GHISLENI, Alexandre Peña. Direitos Humanos e Segurança Internacional: o tratamento dos temas de Direitos Humanos no Conselho de Segurança das Nações Unidas. Brasília: Fundação Alexandre de Gusmão, 2011. p. 32, 42-4, 74. Disponível em: http://funag.gov.br/loja/ download/857-Direitos_Humanos_e_Seguranca_Internacional.pdf. Acesso em: 03 jan. 2018.

GIANNINI, Renata Avelar. A Organização das Nações Unidas e o Desafio das Intervenções Humanitárias. 2008. p. 46. (Mestrado - Programa Interinstitucional PUCSP/UNESP/UNICAMP). São Paulo, 2008. Disponível em: https://repositorio.unesp.br/bitstream/handle/11449/96286/giannini_ra_me_mar. pdf? sequence $=1 \&$ is Allowed $=y$. Acesso em: 22 dez. 2017.

GOUVEIA, Jorce Bacelar. Direito Internacional da Segurança. Coimbra: Almedina, 2013. Livro eletrônico.
GROCIO, Hugo. Del Derecho de La Guerra y de La Paz: Madrid: Reus, 1925.

HABERMAS, Jürgen. Direito e Moral. Lisboa: Instituto Piaget, 1999.

HERZ, Monica; HOFFMAN, Andréa; TABAK, Jana. Organizações Internacionais: história e práticas. Rio de Janeiro: Elsevier Brasil, 2015. Disponível em: https:// books.google.com.br/books?hl=pt-BR\&lr $=\& i d=Q$ ZXpCgAAQBAJ\&oi=fnd\&pg=PT3\&dq=desenvolv imento +histórico + intervenção + humanitária\&ots $=\mathrm{k}$ z7p9NuHNe\&sig=QL51CHYruKFfxI999wUWwF $3 \mathrm{pt} 9 \mathrm{E} \# \mathrm{v}=$ onepage\&q $=$ desenvolvimento $\% 20$ histórico $\% 20$ intervenção $\% 20$ humanitária\&f=false. Acesso em: 4 jan. 2018.

HOLZGREFE, J. H. Humanitarian Intervention: ethical, legal and political dilemmas. Cambridge: Cambridge University Press, 2002. Disponível em: https://books. google.com.br/books?id=luPNuThpx6QC\&printsec $=$ frontcover $\& h l=p t-B R \&$ source $=g b s \_g e \_s u m m a r y \_$ $\mathrm{r} \& \mathrm{cad}=0 \# \mathrm{v}=$ onepage\&q\&f$=$ false. Acesso em: $12 \mathrm{fev}$. 2018.

INTERNATIONAL COMMISSION ON INTERVENTION AND STATE SOVEREIGNTY. The Responsibility to Protect, p. 8, 13, 17, 19-23, 31-7, 39-44, 48, 51, XII, XIII, dez. 2001. Disponível em: http:/ / responsibilitytoprotect.org/ICISS\%20Report.pdf. Acesso em: 8 fev. 2018.

ITUASSÚ, Oyama Cesar. Curso de Direito Internacional Público. Rio de Janeiro: Forense, 1986.

JAMES, Alan. The Peacekeeping Role of the League of Nations. Internations Peacekeeping, v. 6, n. 1, 1999.

JUBILUT, Liliana Lyra. Não Intervenção e Legitimidade Internacional. São Paulo: Saraiva, 2010.

KANT, Immanuel. À Paz Perpétua. São Paulo: L\&PM, 2010 .

KISSINGER, Henry. Diplomacy. New York: Simon \& Schuster, 1994. p. 247. Diponível em: https://archive. org/stream/kissingerdiplomacy4/Henry $\% 20$ Kissinger\%20-\%20Diplomacy\#page/n241/mode/2up/search/247. Acesso em: 22 fev. 2018.

KOSSOVO Comissiont. The Kosovo Report: Conflict, International Response, Lessons Learned. 2000. Disponível em: http://www.oxfordscholarship.com/view/10.1093 /0199243093.001.0001/acprof-9780199243099. Acesso em: 13 fev. 2018. 
LATAROLA. Antonio José. Formação histórica do conceito de soberania. In: MIALHE, Jorge Luis (org.). Direito das Relações Internacionais: Ensaios Históricos e Jurídicos. São Paulo: Milennium, 2007. p. 86-7.

LESSA, Antônio Carlos. Teoria das Relações Internacionais. São Paulo: Saraiva, 2009.

MACHADO, Jónatas Eduardo Mendes. Direito Internacional: do paradigma clássico ao pós-11 de setembro. 3. ed. Coimbra: Coimbra, 2006.

MAZZUOLI, Valerio de Oliveira. Curso de Direito Internacional Público. 8. ed. rev. atual. e ampl. São Paulo: Revista dos Tribunais, 2014.

MELLO, Celso D. De Albuquerque. Curso de Direito Internacional Público. Rio de Janeiro: Renovar, 2001.

MELLO, Celso D. De Albuquerque. Curso de Direito Internacional Público. 6. ed. Rio de Janeiro: Freitas Bastos, 1979.

MELLO, Celso D. De Albuquerque. Direitos Humanos e Conflitos Armados. Rio de Janeiro: Renovar, 1997.

MELLO, Celso D. De Albuquerque. Guerra Interna e Direito Internacional. Rio de Janeiro: Renovar, 1985.

MEZZANOTTI, Gabriela. Direito, Guerra e Terror: Os novos desafios do Direito Internacional pós 11 de setembro. São Paulo: Quartier Latin, 2007.

MIALHE, Jorge Luis. Considerações sobre a história do direito das relações internacionais: jus in bello, guerra justa e a ONU. In: MIALHE, Jorge Luis (org.). Direito das Relações Internacionais: Ensaios Históricos e Jurídicos. São Paulo: Milennium, 2007. p. 157-8.

MOREIRA, Adriano. Teoria das Relações Internacionais. 2. ed. Coimbra: Almedina, 1997.

MOREIRA, Felipe Kern. Direito e Legitimidade na Sociedade Internacional. Boa Vista: Editora da Universidade Federal de Roraima, 2012.

NOGUEIRA, João Pontes; MESSARI, Nizar. Teorias das Relaçoes Internacionais. Rio de Janeiro: Elsevier, 2005.

O DEBATE conceitual sobre intervenção humanitária. p. 37, 77. Disponível em: https://www.maxwell.vrac. puc-rio.br/10564/10564_4.PDF. Acesso em: 3 maio 2018.

ONU. Assembleia Geral. AG Res. 377 (V). 1950.

ONU. Declaração Universal dos Direitos Humanos. UNIC, Rio, 005, ago. 2009. Disponível em: http://
www.onu.org.br/img/2014/09/DUDH.pdf. Acesso em: 12 abr. 2018.

ONUBR. Organizações Unidas no Brasil. A Declaração Universal dos Direitos Humanos. Disponível em: <https:/ / nacoesunidas.org/direitoshumanos/declaracao/ > . Acesso em: 12 abr. 2018.

ONUBR. Organizações Unidas no Brasil. Estatuto da Corte Internacional de Justiça. Disponível em: https://nacoesunidas.org/carta/cij/. Acesso em: 02 maio 2018.

ORTIZ SÁNCHEZ, Luis. ¿ Legitimidad de la Guerra? Uma Revisión a La Teoría de la Guerra Justa. Departament de Filosofia del Dret Moral I Politic Universitat de Valencia. 19 maio 2011. p. 17-9. Disponível em: http:// www.tdx.cat/handle/10803/81306. Acesso em: 5 mar. 2018.

PACTO Briand-Kellog. Disponível em: http://cpdoc. fgv.br/sites/default/files/verbetes/primeira-republica/ PACTO\%20BRIAND-KELLOG.pdf. Acesso em: 4 mar. 2018.

PATRIOTA, Antonio de Aguiar. O Conselho de Segurança após a Guerra do Golfo: a articulação de um novo paradigma de segurança coletiva. Brasília: Instituto Rio Branco, 1998.

PEREIRA, Alexsandro Eugenio. Teoria das Relaçoes Internacionais. Curitiba: Intersaberes, 2016.

PEREIRA, Antônio Celso Alves. A Legítima Defesa no Direito Internacional Contemporâneo. p. 9, 11. Disponível em: http://www.faa.edu.br/revistas/docs/ RID/2010/RID_2010_01.pdf. Acesso em: 11 mar. 2018.

PINTO, Maria do Céu. As Nações Unidas e a Manutenção da Paz: e as actividades de peacekeeping doutras organizações internacionais. Coimbra: Almedina, 2007.

PIOVESAN, Flávia. Direitos Humanos e o Direito Constitucional Internacional. 11. ed. São Paulo: Saraiva, 2010.

RAJCIC, Ivana. Legal Control over Decisions Taken by the United Nations Orgarns and Judicial Review of the Security Council Decisions. Pravnik, v. 48, n. 1, 2014. p. 112. Disponível em: https://hrcak.srce.hr/file/216771. Acesso em: 12 abr. 2018.

RAMOS, André de Carvalho. Processo Internacional de Direitos Humanos: análise dos sistemas de apuração de violações de direitos humanos e implementação das decisões no Brasil. Rio de Janeiro: Renovar, 2002. 
REMIRO BROTONS, Antonio. Derecho internacional público: princípios fundamentales. Madrid: Tecnos, 1983. p. 84-5. In: RICOBOM, Gisele. Intervenção Humanitária: a guerra em nome dos direitos humanos. Belo Horizonte: Fórum, 2010. p. 200.

RESOLUTIONS Adopted and Decisions Taken by the Security Council in 1960. Disponível em: http:// www.un.org/en/ga/search/view_doc.asp?symbol=S/ RES/134(1960). Acesso em: 04 fev. 2018.

REZENDE, Lucas Pereira; AZEVEDO, Cesar Augusto Lambert de. ABRI. Associação Brasileira de Relações Internacionais. Carta Internacional. Sobre o Sistema de Segurança Coletiva e a Legitimidade das Operações de Paz. da ONU, v. 6, n. 1, p. 24, 2011. Disponível em: https:// cartainternacional.abri.org.br/Carta/article/view/22. Acesso em: 28 mar. 2018.

RICOBOM, Gisele. Intervenção Humanitária: a guerra em nome dos direitos humanos. Belo Horizonte: Fórum, 2010 .

RODRIGUES, Simone Martins. Segurança Internacional e Direitos Humanos: a prática da intervenção humanitária no pós-Guerra Fria. Rio de Janeiro: Renovar, 2000.

ROSAS, Gustavo Ludwig Ribeiro. Legalidade da Intervenção Humanitária. Disponível em: http://re.granbery. edu.br/artigos/MjA0.pdf Acesso em: 10 jan. 2018.

ROSSI, Flávia. A Guerra do Kosovo: Uma questão humanitária? Revista Mediações, Londrina, v. 7, n. 2, p. 1IJ3·131, jul./dez. 2002. p. 110. Disponível em: http:/ / www.uel.br/revistas/uel/index.php/mediacoes/article/view/9100/7655. Acesso em: 3 maio 2018.

SALIHU, Arben. NATO Intervention in Kosovo in light of Security Council Actions and International Law. ILIRIA International Review, v. 3, n. 2, p. 285-303, dez. 2013. Disponível em: http://iliriapublications.org/index.php/iir/article/view/130/122. Acesso em: 3 maio 2018.

SPIELER, Paula. A indeterminação do conceito de intervenção humanitária. Direito, Estado e Sociedade, n. 31 p. 9, 56, jul./dez. 2007. Disponível em: http://www. jur.puc-rio.br/revistades/index.php/revistades/article/ view/265/240. Acesso em: 12 jan. 2018.

SUT'TERLIN, James S. The United Nations and the Maintenance of International Security. A Challenge To Be Met. Praeger. 1995. p. 3. Disponível em: https://books.google.com.br/books?hl=pt-BR\&lr=\&id $=d Y i s t Z d$
U8AQC\&oi=fnd\&pg $=$ PA1\&dq=The + United + Nation $\mathrm{s}+$ and + the + Maintenance $+\mathrm{of}+$ International + Security \&ots $=$ cdu8pexCPS\&sig $=$ xYGa9I-08Dqc4cAhbuqrg0$678 \mathrm{w} \#_{\mathrm{v}}=$ onepage\&q\&f=false. Acesso em: 28 mar. 2018.

SWINARSKI. Christophe. Introdução ao Direito Internacional Humanitário. Brasília: Comitê Internacional da Cruz Vermelha e Instituto Interamericano de Direitos Humanos, 1996.

TESÓN, Fernando R. Humanitarian Intervention: an inquiry into law and morality. 2. ed. New York: Transnational, 1997.

TESÓN, Fernando R. Kosovo: a powerful precedente for the doctrine of humanitarian intervention. Amsterdam Law Fórum, v. 1, n. 2, p. 41-8, 2009. Disponível em: http://amsterdamlawforum.org/article/view/62/119. Acesso em: 3 maio 2018.

TESÓN, Fernando R. The Vexing Problem of Authority in Humanitarian Intervention: a proposal. Wisconsin International Law Journal, v. 24, n. 3, 2006. Disponível em: http://hosted.law.wisc.edu/wordpress/wilj/files/2012/02/teson.pdf. Acesso em: 11 mar. 2018.

The Future of UN Human Rights Treaty Monitoring. Cambridge: Cambridge University Press, 2000.

THE Kosovo Comission. The Independent International Comissiono on Kosovo. p. 5. Disponível em: https://reliefweb.int/sites / reliefweb.int/files / resources /6D26F F88119644CFC1256989005CD392-thekosovoreport. pdf. Acesso em: 3 maio 2018.

This is the testimony of Uyisenga, a survivor of the Rwandan genocide. SURF - Survivors Fund. Disponível em: http://www.un.org/en/preventgenocide/ rwanda/testimonies/pdf/13\%20-\%20Uyisenga $\% 20$ 2009.pdf. Acesso em: 9 fev. 2018.

TODOROV, Tzvetan. Os limites da Justiça. In: CASSESE, Antonio; DELMAS-MARTY, Mireille (org.). Crimes Internacionais e Jurisdições Internacionais. São Paulo: Manole, 2004. p. 47.

TRINDADE, Antônio Augusto Cançado. A Proteção Internacional dos Direitos Humanos: Fundamentos jurídicos e instrumentos básicos. São Paulo: Saraiva, 1991.

TRINDADE, Antônio Augusto Cançado. A Proteção Internacional dos Direitos Humanos e o Brasil (1948-1997): As primeiras cinco décadas. Brasília: Universidade de Brasília, 1998. 
TRINDADE, Antônio Augusto Cançado; SANTIAGO, Jaime Ruiz de. La Nueva Dimensión de las Necesidades de Protección del Ser Humano en el Inicio del Siglo XXI. 2. ed. San José, C.R: Impresora Gossestra Internacional, 2002. p. 63-9. Disponível em: http://www.acnur.org/ t3/fileadmin/Documentos/Publicaciones/2012/8946. pdf?view=1. Acesso em: 13 abr. 2018.

UZIEL, Eduardo. O Conselho de Segurança, as Missões de Paz e o Brasil no Mecanismo de Segurança das Nações Unidas. Brasília: FUNAG, 2015.

VINCENT. No Intervención y Orden Internacional [1]. Chile/ Buenos Aires: Marymar, 1976. p. 19. Disponível em: https://www.maxwell.vrac.puc-rio.br/10564/10564_3. PDF. Acesso em: 13 jan. 2018.

WALZER, Michael. Guerras Justas e Injustas: uma argumentação moral com exemplos históricos. São Paulo: Martins Fontes, 2003.

WALZER, Michael. Just and Unjust Wars: a moral argument with historical illustrations. Basic Books, 11 ago. 2015. Disponível em: https://books.google.com.br/bo oks?id=EuTQCQAAQBAJ\&printsec $=$ frontcover\&hl
$=\mathrm{pt}-\mathrm{BR} \&$ source $=\mathrm{gbs} \_\mathrm{ge} \_$summary_r\&cad $=0 \# \mathrm{v}=$ one page\&q\&f=false. Acesso em: 22 nov. 2017.

WHEELER, N. Review article: Humanitarian intervention after Kosovo: emergent norm, moral duty or the coming anarchy? International Affairs, v. 77, n. 1, p. 113, jan. 2001.

WHEELER, N. Saving Strangers: Humanitarian Intervention in International Society. OUP Oxford, 7 de set de 2000. p. 34-5. Disponível em: https:// books.google.com.br/books?id=AYQLyuN4_ twC\&printsec $=$ frontcover\&hl $=$ pt $-B R \&$ source $=$ gbs_ ge_summary_r\&cad $=0 \# \mathrm{v}=$ onepage $\& \mathrm{q} \& \mathrm{f}=$ false. Acesso em: 2 abr. 2018.

WISE, Laura. Was Nato's Intervention in Kosovo in 1999 'Just'? E-International Relations, 21 jun. 2013. Disponível em: <http://www.e-ir.info/2013/06/21/wasnatos-intervention-in-kosovo-in-1999-just/>. Acesso em: 11 dez. 2017.

ZOLO, Danilo. La Justicia de los Vencedores: de Nuremberg a Bagdad. Madrid: Trotta, 2007. 
Para publicar na Revista de Direito Internacional, acesse o endereço eletrônico www.rdi.uniceub.br ou www.brazilianjournal.org.

Observe as normas de publicação, para facilitar e agilizar o trabalho de edição. 